\title{
Maternal transmission of Alzheimer's disease: Prodromal metabolic phenotype and the search for genes
}

\author{
Lisa Mosconi, ${ }^{* *}$ Valentina Berti, ${ }^{2}$ Russell H. Swerdlow, ${ }^{3}$ Alberto Pupi, ${ }^{2}$ Ranjan Duara ${ }^{4}$ and Mony de Leon ${ }^{1,5}$ \\ 'Center for Brain Health, New York University School of Medicine, New York, NY 10016, USA \\ ${ }^{2}$ Nuclear Medicine Unit, University of Florence, Careggi Hospital, 50134 Florence, Italy \\ ${ }^{3}$ Landon Center on Aging, MS2012, Kansas City, KS 66160-7401, USA \\ ${ }^{4}$ Wien Center for Alzheimer's Disease and Memory Disorders, Mount Sinai Medical Center, Miami Beach, and Miller School of \\ Medicine, University of Miami, Miami, FL 33140, USA \\ ${ }^{5}$ Nathan Kline Institute, Orangeburg, NY 1096, USA \\ *Correspondence to: Tel: +1 212263 3255; Fax: +1 212263 3270; E-mail: lisa.mosconi@nyumc.org
}

Date received (in revised form): 11th November, 2009

\begin{abstract}
After advanced age, having a parent affected with Alzheimer's disease (AD) is the most significant risk factor for developing $A D$ among cognitively normal $(N L)$ individuals. Although rare genetic mutations have been identified among the early-onset forms of familial AD (EOFAD), the genetics of the more common forms of late-onset $A D$ (LOAD) remain elusive. While some LOAD cases appear to be sporadic in nature, genetically mediated risk is evident from the familial aggregation of many LOAD cases. The patterns of transmission and biological mechanisms through which a family history of LOAD confers risk to the offspring are not known. Brain imaging studies using 2-[ $\left.{ }^{18} \mathrm{~F}\right]$ fluoro-2-deoxy-D-glucose positron emission tomography ( ${ }^{18} \mathrm{~F}-\mathrm{FDG}$ PET) have shown that NL individuals with a maternal history of LOAD, but not with a paternal family history, express a phenotype characterised by a pattern of progressive reductions of brain glucose metabolism, similar to that in AD patients. As maternally inherited AD may be associated with as many as 20 per cent of the total LOAD population, understanding the causes and mechanisms of expression of this form of $A D$ is of great relevance. This paper reviews known genetic mutations implicated in EOFAD and their effects on brain chemistry, structure and function; epidemiology and clinical research findings in LOAD, including in vivo imaging findings showing selective patterns of hypometabolism in maternally inherited $A D$; possible genetic mechanisms involved in maternal transmission of $A D$, including chromosome $\mathrm{X}$ mutations, mitochondrial DNA and imprinting; and genetic mechanisms involved in other neurological disorders with known or suspected maternal inheritance. The review concludes with a discussion of the potential role of brain imaging for identifying endophenotypes in NL individuals at risk for $A D$, and for directing investigation of potential susceptibility genes for AD.
\end{abstract}

Keywords: Alzheimer's disease, late onset, maternal transmission, early detection, positron emission tomography

\section{Alzheimer's disease: Incidence and clinical profile}

Alzheimer's disease (AD) is the most common form of dementia in late life, affecting approximately 10 per cent of individuals of 65 years of age, with the prevalence doubling every five years up to the age of 80 , above which the prevalence is 40 per cent. ${ }^{1}$ In 2008, in the United States alone, there were more than 5 million people with $\mathrm{AD}$, which is a 10 per cent increase from the previous (in 2000) prevalence estimate of 4.5 million (Figure 1, adapted from 

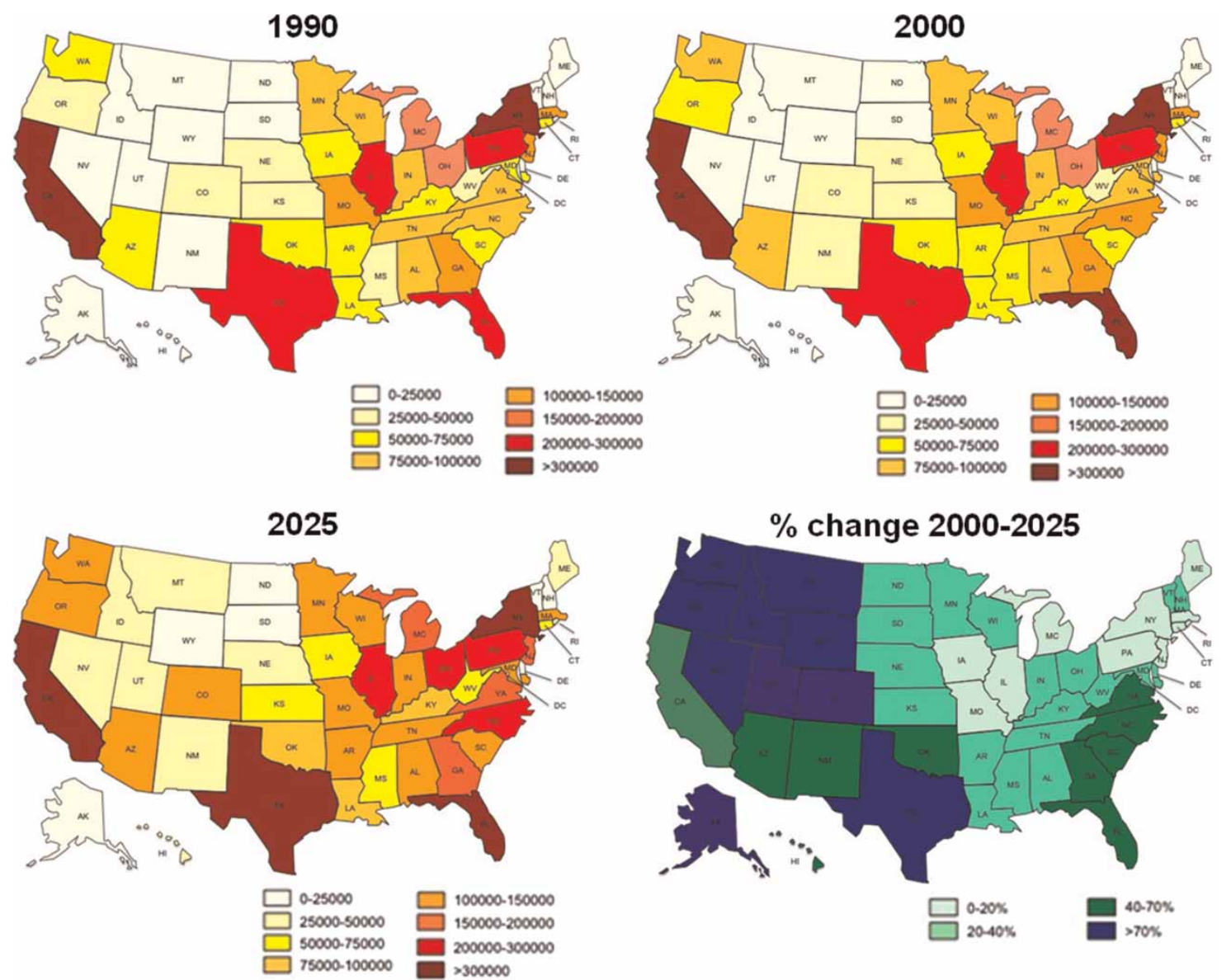

Figure I. Incidence of AD cases in the USA. State-specific projections up to 2025 (adapted from Hebert et al. ${ }^{2}$ ).

Hebert et al. ${ }^{2}$ ). Age-related mild cognitive impairments may affect two to three times as many individuals. $^{3,4}$ By 2050, the number of elderly people with $\mathrm{AD}$ in the USA could range from 11 million to 16 million, which strongly calls for strategies to prevent or delay the onset of the disease.

$\mathrm{AD}$ is a neurodegenerative disorder characterised by global deficits in cognition, ranging from memory loss to impaired judgment and reasoning. ${ }^{5}$ Clinical diagnosis per se is often uncertain and clinical assessment requires multiple examinations and laboratory tests over time. Despite thorough clinical exams, the frequency of unrecognised dementia in the community ranges from 50 per cent to 90 per cent of cases. ${ }^{6}$ Insidious onset and progressive impairment of memory and other cognitive functions make the initial stages of AD difficult to distinguish from so called 'normal ageing'. In order to develop prevention treatments for $\mathrm{AD}$, it is necessary to identify persons who are still cognitively normal (NL), but are either at very high risk for developing the disease or are in an early, presymptomatic stage of the disease. Such individuals are most likely to benefit from therapies which are instituted when the potential for preservation of function is the greatest, well before irreversible synaptic and neuronal injury.

The difficulty in studying the genetics of complex, age-associated disorders such as late onset AD (LOAD) using traditional clinical case identification measures has resulted in an increasing emphasis on studying endophenotypes of AD, which provide more specific targets for genetic studies. In 2007, it was shown that NL children of mothers affected with LOAD express a biological phenotype characterised by progressive reductions in brain 
glucose metabolism in the same brain regions as clinical AD patients, as measured on $2-\left[{ }^{18} \mathrm{~F}\right]$ fluoro-2-deoxy-D-glucose positron emission tomography $\left({ }^{18}\right.$ F-FDG PET). ${ }^{7}$ By contrast, children of AD-affected fathers and of parents with no dementia did not show metabolic abnormalities. ${ }^{7}$ The genetic basis for the selective maternal transmission of metabolic deficits in AD is not known.

The present review first summarises known genetic mechanisms involved in the early- and late-onset forms of $\mathrm{AD}$, and in vivo brain imaging studies that provide a link between genetics, pathology and pathophysiology in $\mathrm{AD}$. It then presents recent findings of progressive reductions in brain glucose metabolism in adult children of mothers affected with LOAD, and discusses possible genetic and epigenetic mechanisms involved in maternally inherited brain hypometabolism. Finally, it examines other neurological disorders with known or suspected maternal transmission, and discusses the role of imaging in identifying endophenotypes in preclinical AD.

Although many imaging methods are available, this review will focus on the two most widely utilised brain imaging techniques in both clinical practice and research studies in $\mathrm{AD}$ - magnetic resonance imaging (MRI) and PET. Various MRI and PET studies in $\mathrm{AD}$ have been published recently. ${ }^{8-13}$ Briefly, these methods have long been used in $\mathrm{AD}$ for the detection of structural brain changes and volume reductions due to neuronal loss (ie atrophy) on MRI, and reductions of cerebral metabolic rate of glucose (CMRglc) on ${ }^{18}$ F-FDG-PET. Both modalities accurately discriminate $\mathrm{AD}$ from controls, predict decline from normal cognition to dementia and correlate with disease progression and histopathological diagnosis. ${ }^{8-13}$ In addition, ${ }^{18}$ F-FDG-PET has the advantage of being particularly useful for distinguishing AD from other forms of dementia. ${ }^{10-13}$ Overall, AD patients present with brain atrophy and hypometabolism in the parieto-temporal, posterior cingulate, medial temporal and prefrontal cortex, while the primary motor and visual areas, cerebellum, thalamus and basal ganglia are relatively spared. $^{8-13}$
In addition to traditional imaging techniques, a turning point in AD was accomplished with the recent development of PET tracers for amyloidbeta $(A \beta)$ plaques, which allow examination of $A \beta$ deposits in vivo. Among different amyloid PET ligands, the best characterised is the N-methyl$\left[{ }^{11} \mathrm{C}\right] 2-\left(4^{\prime}\right.$-methylaminophenyl)-6-hydroxybenzothiazole, also known as Pittsburgh compound-B $\left({ }^{11} \mathrm{C}-\mathrm{PIB}\right) .{ }^{14} \mathrm{AD}$ patients consistently show ${ }^{11} \mathrm{C}-\mathrm{PIB}$ uptake in amyloid-rich brain regions, particularly in the frontal, parieto-temporal, posterior cingulate, precuneus and occipital cortices, as well as the thalamus and striatum, whereas the control population mostly showed non-specific binding restricted to the white matter. ${ }^{8,15,16-18}$ A combination of imaging modalities may help to make an earlier diagnosis, and to define the nature and extent of $\mathrm{AD}$ pathology among pre-symptomatic individuals.

\section{Autosomal dominant genetic transmission of AD: The early-onset forms}

The three genes that are causative of $A D$

A central role for $A \beta$ in $A D$ is strongly supported by studies of the rare early-onset ( $<60$ years) forms of familial AD (EOFAD). Genetic factors that have been firmly implicated in EOFAD are mutations in the amyloid precursor protein $(A P P)$, presenilin 1 (PSEN1) and presenilin 2 (PSEN2) genes, which are found in large multi-generational families with an autosomal dominant pattern of disease inheritance. Major findings from studies of EOFAD mutation carriers are summarised in Table 1.

In 1990, the first mutation in the gene encoding APP, on chromosome 21, was discovered in a pedigree with Dutch-type hereditary cerebral haemorrhage with amyloidosis. Shortly after, a missense mutation occurring in the same APP exon (exon 17) was detected in patients with EOFAD. ${ }^{19,20}$ Although APP mutations account for less than 0.1 per cent of all AD cases, they have virtually complete penetrance. ${ }^{19,20}$ Only a year later, a second EOFAD locus was linked to chromosome 14, and the gene was later identified as PSEN1. ${ }^{20}$ PSEN1 
Table I. Genes associated with Alzheimer's disease

\begin{tabular}{|c|c|c|c|c|c|c|}
\hline Gene & Chromosome & Transmission & $\begin{array}{c}\text { AD } \\
\text { form }\end{array}$ & Prevalence & Clinical characteristics & $\begin{array}{l}\text { In vivo imaging } \\
\text { findings }\end{array}$ \\
\hline APP & 21 & $\begin{array}{l}\text { Autosomal } \\
\text { dominant }\end{array}$ & EOFAD & $\begin{array}{l}10-15 \% \text { of } \\
\text { EOFAD }\end{array}$ & $\begin{array}{l}\text { Age of onset }<65 \text { years } \\
\text { Increased processing of } \\
\text { APP to } A \beta_{42}\end{array}$ & $\begin{array}{l}\text { Reduced CMRglc on } \\
\text { FDG-PET in } \\
\text { pre-symptomatic and } \\
\text { symptomatic mutation } \\
\text { carriers }\end{array}$ \\
\hline APP & 21 & $\begin{array}{l}\text { Autosomal } \\
\text { recessive }\end{array}$ & EOFAD & na & $\begin{array}{l}\text { Age of onset }<50 \text { years } \\
\text { Increased } A \beta \text { production }\end{array}$ & na \\
\hline PSENI & 14 & $\begin{array}{l}\text { Autosomal } \\
\text { dominant }\end{array}$ & EOFAD & $\begin{array}{l}30-70 \% \text { of } \\
\text { EOFAD }\end{array}$ & $\begin{array}{l}\text { Age of onset } 40-50 \text { years } \\
\text { Increased processing of } \\
\text { APP to } A \beta_{42} \\
\text { Rapid progression } \\
\text { Associated with seizures, } \\
\text { myoclonus and language } \\
\text { deficits }\end{array}$ & $\begin{array}{l}\text { Reduced CMRglc on } \\
\text { FDG-PET and striatal } \\
\text { amyloid deposition on } \\
\text { PIB PET in } \\
\text { pre-symptomatic and } \\
\text { symptomatic mutation } \\
\text { carriers }\end{array}$ \\
\hline PSEN2 & I & $\begin{array}{l}\text { Autosomal } \\
\text { dominant }\end{array}$ & EOFAD & $\begin{array}{l}<5 \% \text { of } \\
\text { EOFAD }\end{array}$ & $\begin{array}{l}\text { Age of onset } 40-70 \text { years } \\
\text { Increased } A \beta_{42} \\
\text { production }\end{array}$ & na \\
\hline ApoE & 19 & $\begin{array}{l}3 \text { allelic } \\
\text { variants: } \varepsilon 2 \text {, } \\
\varepsilon 3, \varepsilon 4\end{array}$ & LOAD & $\begin{array}{l}40 \% \text { of } \\
\text { LOAD, } \\
10-20 \% \text { of } \\
\text { controls }\end{array}$ & $\begin{array}{l}\text { ApoE } \varepsilon 4 \text { carriers vs } \\
\text { non-carriers show lower } \\
\text { age at onset, reduced } A \beta \\
\text { clearance, poorer } \\
\text { cognitive performance in } \\
\text { late life }\end{array}$ & $\begin{array}{l}\text { Hippocampal atrophy } \\
\text { on MRI and reduced } \\
\text { CMRglc on FDG-PET } \\
\text { in pre-symptomatic and } \\
\text { symptomatic ApoE } 84 \\
\text { carriers vs non-carriers }\end{array}$ \\
\hline SORLI & II & $\begin{array}{l}\text { SNPs: } 8-10 \\
\text { and } 22-25 \\
\text { gene regions }\end{array}$ & LOAD & $\begin{array}{l}20-40 \% \text { of } \\
\text { LOAD }\end{array}$ & Increased $A \beta$ production & $\begin{array}{l}\text { Hippocampal atrophy } \\
\text { on MRI in SORLI } \\
\text { carriers vs non-carriers }\end{array}$ \\
\hline KIBRA & 5 & SNP: $\mathrm{T} \rightarrow \mathrm{C}$ & LOAD & $\begin{array}{l}45 \% \text { of } \\
\text { LOAD }\end{array}$ & $\begin{array}{l}\text { Poorer episodic memory } \\
\text { in CC carriers vs } T T \text { and } \\
T C \text { carriers }\end{array}$ & $\begin{array}{l}\text { Increased hippocampal } \\
\text { activation on } \mathrm{fMRI} \text {, and } \\
\text { reduced CMRglc on } \\
\text { FDG-PET in CC } \\
\text { carriers vs CT and TT } \\
\text { carriers }\end{array}$ \\
\hline GAB2 & II & 6 SNPs & LOAD & $\begin{array}{l}70 \% \text { of } \\
\text { LOAD }\end{array}$ & $\begin{array}{l}\text { CT-AAG- } \\
\text { CAGATCAGACG vs } \\
\text { TC-GCA- } \\
\text { TGAGGTGTCTT } \\
\text { haplotype: Less } \\
\text { protection from neuronal } \\
\text { tangle formation and cell } \\
\text { death Increased risk of } \\
\text { AD }\end{array}$ & na \\
\hline PCDHIIX & $x$ & $\begin{array}{l}\text { SNP: } \\
\text { Rs5984894 }\end{array}$ & LOAD & na & Increased risk of $A D$ & na \\
\hline
\end{tabular}

EOFAD = early onset familial Alzheimer's disease; CMRglc = cerebral metabolic rate of glucose; na = not available; FDG-PET = fluoro-2-deoxy-D-glucose positron emission tomography; PIB-PET = Pittsburgh Compound-B PET; LOAD = late onset AD; MRI = magnetic resonance imaging. 
is fully penetrant, has an age of onset of disease between 28 and 65 years and is responsible for the majority of EOFAD mutations identified thus far. A second presenilin gene (PSEN2), on chromosome 1, is responsible for six other EOFAD mutations. On average, EOFAD mutations in PSEN2 exhibit a later age of onset of disease (ranging from 43 to 80 years) than those in APP or PSEN1. ${ }^{19,20}$

\section{The pathophysiology associated with EOFAD genes}

Studies of the effects of these genetic mutations suggested a central role for $A \beta$ in the pathogenesis of $\mathrm{AD}$. Definitive diagnosis of $\mathrm{AD}$ requires postmortem observation of specific pathological lesions: $\mathrm{A} \beta$ plaques, neurofibrillary tangles (NFT) containing hyperphosphorylated tau protein, synaptic loss and brain atrophy in specific brain areas. ${ }^{21,22}$

EOFAD mutations in the APP and PSEN genes generally shift the processing of $A P P$ to $A \beta_{42}$, leading to an increased ratio of $A \beta_{42}$ to $A \beta_{40}$ (Table 1$).{ }^{20}$ At post-mortem, EOFAD cases consistently show substantial AD pathology - particularly diffuse and numerous $A \beta$ plaques surrounded by activated microglia - associated with extensive synaptic loss and brain atrophy. ${ }^{20} \mathrm{~A} \beta$ peptides are formed from APP and cluster into amyloid plaques on the blood vessels and in the extraneuronal space. $^{23,24}$ A $\beta$ peptides are toxic to cell cultures. ${ }^{25,26}$ Ageing appears to render the brain more vulnerable to $A \beta$ toxicity, ${ }^{27}$ and $A \beta$ further impairs mitochondrial function in ageing brains and initiates a neurotoxic cascade with parallel overproduction of free radicals. ${ }^{28}$ In $A D, A \beta$ pathology was shown to occur upstream of tau pathology, and recent studies have shown that $A \beta$ may lead to NFT formation within cells. ${ }^{29}$ Nonetheless, a causal relationship between $A \beta$ and tau pathology in $\mathrm{AD}$ remains to be clarified.

Clinically, EOFAD is characterised by a specific age of onset of cognitive impairment for a given pedigree. Therefore, studies of pre-symptomatic mutation carriers close to the expected age of onset provide unique information about preclinical AD-related brain changes. Asymptomatic and symptomatic PSEN1 mutation carriers showed significant reductions in brain tissue (ie atrophy) on MRI and in global CMRglc on FDG-PET, as compared with age-matched controls. ${ }^{30}$ CMRglc reductions on FDG-PET were shown to exceed MRI volume loss in pre-symptomatic PSEN1 carriers. $^{31}$

Amyloid imaging with ${ }^{11} \mathrm{C}-\mathrm{PIB}$ PET showed higher amyloid load in both asymptomatic and symptomatic individuals carrying PSEN1 mutations compared with controls. ${ }^{32}{ }^{11} \mathrm{C}-\mathrm{PIB}$ retention was especially high in the striatum of all PSEN1 mutation carriers compared with controls and sporadic AD patients. Symptomatic mutation carriers showed significant tracer retention also in the cortical regions, although uptake was not as high as in sporadic AD subjects. ${ }^{32}$ These findings suggest that amyloid deposition in PSEN1 mutation carriers may begin in the striatum before the onset of symptoms, and later spread to neocortical regions. ${ }^{32,33}$ The data may also point to different patterns of $A \beta$ deposition in $A D$, however, with the striatum being more affected in EOFAD and the cortex being more affected in the late-onset forms. A similar pattern of prominent ${ }^{11} \mathrm{C}-\mathrm{PIB}$ retention in the striatum, especially in the caudate nucleus and putamen, was also found in EOFAD patients with $A P P$ mutations. ${ }^{34}$

\section{$A P P$ recessive mutations}

While most studies demonstrated an association between autosomal dominant APP mutations and EOFAD forms, a recent study identified a mutation in the APP gene $(A 673 V)$ that causes AD only in the homozygous state, reflecting recessive Mendelian inheritance. ${ }^{35}$ Affected carriers presented at 36 years of age with behavioural changes and cognitive deficits, leading to severe dementia, spastic tetraparesis and a complete loss of autonomy. ${ }^{35}$ This APP mutation was shown in vitro to have two pathogenic effects: shifting of APP processing toward the amyloidogenic pathway and enhancement of the aggregation of fibrillogenic $\mathrm{A} \beta \mathrm{.}^{35}$ Among heterozygotes, the interaction between wild-type and mutant $A \beta$ produced by the non-mutated and mutated alleles appeared to 
hinder amyloidogenesis and neurotoxicity, thus protecting heterozygous carriers from developing the clinical syndrome.

Another homozygous APP mutation (A693D) resulted in clinical $\mathrm{AD}$ among three $\mathrm{AD}$ patients from a Japanese pedigree. ${ }^{36}$ A heterozygous member of the same family was found to have mild cognitive impairment (MCI), which may lead to $\mathrm{AD}^{36}$ It remains to be established whether $A 693 D$ is a recessive mutation or a dominant $A P P$ variant with incomplete penetrance.

\section{LOAD and the role of risk-modifying genes}

The lesson learned from studying APP and PSEN mutations is that $A \beta$ dysmetabolism may be a primary event in the pathogenesis of EOFAD. Whether this mechanism of action of $A \beta$ leads to the more common, late-onset forms of AD remains to be determined. While the rare EOFAD cases have autosomal dominant inheritance and the onset and progression of the disease appears relatively independent of non-genetic factors, LOAD, which comprises 99 per cent of the AD population after the age of 60 , does not seem to be associated with clearly discernible nuclear genetic mutations. Several genetic and non-genetic factors influence the risk for the development of LOAD and modify both the age at onset and the course of the disease. These include genes (predisposing risk alleles), sociodemographic background (education, intellectual engagement), lifestyle (diet, fitness), environment and medical history (head trauma, medications, smoking, vascular diseases, etc).

Studies of monozygotic (MZ) and dizygotic (DZ) twins affected by LOAD suggest that genetic influence may predominate over environmental influence. ${ }^{37,38}$ In a twin study, a twin pair can either be concordant (both individuals have the disorder) or discordant (only one of two is affected). MZ twins share all of their chromosomes, while DZ twins do not. Therefore, evidence that MZ twins are more concordant for AD than DZ twins would indicate stronger genetic influence. Evidence for the role of the environment comes from $\mathrm{MZ}$ twins who are discordant for the disease. Results from Swedish and Finnish twin registries have shown high rates of concordance for AD (over 80 per cent for MZ and 46 per cent for DZ) and high heritability ( $\geq 74$ per cent). ${ }^{38,39}$ Genetic influence on the age of onset of $\mathrm{AD}$ is demonstrated by the fact that it was more concordant for $\mathrm{MZ}$ compared with DZ twin pairs. ${ }^{38}$

The challenge in identifying genetic factors involved in LOAD may be due to a combination of variables, which include its insidious onset and slow progression, the complexity of most age-related conditions, the variable influence of various environmental and medical conditions often over a period of decades and the lack of sensitive and specific criteria for incipient AD. Because it is necessary for other family members to survive until the age of onset of the disease, cases may not be recognised as being familial. Genetic association studies in LOAD have identified single DNA sequence variations within a single nucleotidethat is, single nucleotide polymorphisms (SNPs; these are DNA sequence variations that occur when a single nucleotide $[A, T, C$ or $G]$ in the genome sequence is altered) or haplotypes (ie a combination of alleles at multiple loci that are transmitted together on the same chromosome, or can be defined as a set of SNPs on a single chromosome that are statistically associated) - that are associated with increased risk. Although several SNPs within specific genes have been reported to be associated with LOAD, this review will focus on more widely studied polymorphisms in five genes: apolipoprotein $\mathrm{E}(A p o E)$, sortilin-related receptor 1 (SORL1), growth factor receptor bound (GRB)-associated binding protein 2 (GAB2), protocadherin 11 (PCDH11X) and kidney and brain $(\operatorname{KIBR} A)$ genes. Major findings from studies of susceptibility genes involved with LOAD are summarised in Table 1.

\section{ApoE}

In 1993, Strittmatter and colleagues discovered that carriers of the epsilon $4(\varepsilon 4)$ allele of the gene encoding ApoE, located on chromosome 19, are at higher risk for AD than non-carriers. ${ }^{40}$ ApoE 
contains two SNPs that result in three possible alleles for this gene: $\varepsilon 2, \varepsilon 3$ and $\varepsilon 4$. Each allele differs by one DNA base, and the protein product of each gene differs by one amino acid. Case-control studies showed that the ApoE $\varepsilon 4$ genotype occurs in approximately 40 per cent of all LOAD patients and is also over-represented in EOFAD. ${ }^{19}$ Animal and human studies suggest that the association of the $A p o E \varepsilon 4$ allele with $\mathrm{AD}$ is mediated primarily by a dose-dependent effect of the $\varepsilon 4$ allele on the deposition of $A \beta$ in the brain. ${ }^{41-45}$ Some have speculated that ApoE may also influence AD risk by disrupting microtubuleassociated tau protein metabolism. ${ }^{19,46}$

MRI studies have demonstrated an association between the $\varepsilon 4$ allele and hippocampal atrophy, with the rate of hippocampal volume loss being greater for the $\varepsilon 4$ carriers than for the noncarriers. ${ }^{47,48}{ }^{18}$ F-FDG PET studies showed that, compared with non-carriers, asymptomatic carriers of the ApoE $\varepsilon 4$ genotype show CMRglc reductions within the brain regions typically affected in clinical AD patients. ${ }^{49}$ They also showed greater CMRglc declines over time. ${ }^{49}$ Despite its well-established association with $\mathrm{AD}$, the $A p o E \varepsilon 4$ genotype has no clear familial pattern of transmission and appears to act as a risk modifier by lowering the age at onset of clinical symptoms, rather than as a causal determinant. ${ }^{19,50-52}$.

\section{SORL1}

Recent studies have shown an association between SORL1, located on chromosome 11, and LOAD. Genetic changes in SORL1 expression appear to be causally linked to the pathogenesis of $\mathrm{AD}$ and to increased risk for the disease. ${ }^{53}$ In particular, SNPs in different regions of SORL1 were associated with AD in multiple ethnically diverse samples ${ }^{53-55}$ and also in the Translational Genomics Research Institute (TGEN) database. ${ }^{56}$ Evidence for various AD-associated haplotypes supports the notion that there may be a high degree of allelic heterogeneity, with disease-associated variants occurring on multiple different haplotypic backgrounds.

SORL1 encodes a protein that modulates subcellular trafficking of $\mathrm{APP}^{53}$ Reduced expression of
SORL1 leads to release of APP into endosomal pathways, where it is subjected to beta- and gamma-secretase cleavage, with subsequent production of $A \beta$. The SORL1 protein also belongs to a superfamily of low-density lipoprotein receptors (SorLA/LR11) which bind ApoE and are implicated in cholesterol metabolism and atherogenesis. There is evidence for reduced SORL1 expression in the brains of patients with $\mathrm{AD},{ }^{57}$ which was found to be associated with increased $\mathrm{A} \beta$ production. ${ }^{58}$ In $\mathrm{AD}$ patients, SORL1 variants associated with AD are also associated with wholebrain and hippocampal atrophy on MRI. ${ }^{59}$ Heterogeneity still remains in SORL1 alleles, however, and broad regions of SORL1 still need to be examined for functional pathogenic variants.

\section{$G A B 2$}

$G A B 2$, on chromosome 11q, was recently identified as a susceptibility gene for LOAD. $^{60} \mathrm{~A}$ genome-wide association study reported that a haplotype encompassing six polymorphisms of the GAB2 gene is associated with a higher risk of developing $\mathrm{AD},{ }^{60,61}$ especially in $A p o E \varepsilon 4$ allele carriers. ${ }^{61}$ The hypofunctional GAB2 haplotype is thought to be associated with a reduced GAB2-protective effect on neurones. GAB2 is a scaffolding protein involved in multiple signalling pathways, which is thought to protect cells from NFT formation and cell death. ${ }^{62}$ Neuronal microarray studies provided evidence that GAB2 is biologically relevant to AD neuropathology by showing that LOAD cases had significantly greater neuronal GAB2 expression in the posterior cingulate cortex and hippocampus than controls. ${ }^{60}$ The relationship between GAB2 polymorphisms and $\mathrm{A} \beta$ metabolism has not yet been established.

\section{PCDH11X}

PCDH11X is a gene located on chromosome $\mathrm{X}$ encoding protocadherin 11. Protocadherin belongs to the cadherin family of cell surface receptor molecules. The cadherin proteins mediate cell-cell adhesion and have a role in cell signalling that is critical in the development of the central nervous system. Notably, some protocadherins are known to 
undergo presenilin-dependent processing. ${ }^{63}$ A genome-wide association study identified a SNP on chromosome $\mathrm{X}$ which resides in a haplotype block that falls entirely within PCDH11X and strongly segregated with LOAD. ${ }^{64}$ Female homozygotes showed a significantly increased risk for $\mathrm{AD}$ compared with female non-carriers, female heterozygotes and male hemizygotes. ${ }^{64}$ Moreover, female heterozygotes were at increased risk over female non-carriers, and male hemizygotes were at higher risk than male noncarriers. ${ }^{64}$ To obtain a perspective about the importance of PCDHX11 to LOAD, it is useful to compare the risk for LOAD associated with PCDHX11 with that for ApoE. The odds ratio for LOAD associated with the homozygous ApoE $\varepsilon 4$ allele is 11.5 , whereas for homozygous PCDH11X it is 1.75 (http://www.physorg.com/news1509055 04.html). These results await replication.

\section{KIBRA alleles}

Recent genome-wide studies aimed at identifying memory-related gene variants have shown an association between the KIBRA gene on chromosome $5 \mathrm{q}$ and human memory performance. ${ }^{65,66}$ KIBRA is a cytoplasmic protein that is highly expressed in the brain and is a binding partner of dendrin, a putative modulator of synaptic plasticity. A SNP within the ninth intron of KIBRA was shown to influence episodic memory. ${ }^{65}$ There are two allelic variants of KIBRA (T and $\mathrm{C}$ ), which result in three possible genotypes: TT, CT and CC. KIBRA $T$ allele carriers (CT and TT genotypes) had better episodic memory performance than KIBRA CC carriers in young, middle-aged and elderly subjects. ${ }^{65,66}$ Moreover, KIBRA CC carriers had a moderate but significantly increased risk of AD compared with TT and CT carriers. ${ }^{67,68}$

In functional MRI (fMRI) studies, KIBRA CC carriers showed greater activation of the hippocampus and frontal and parietal cortex compared with the $T$ allele carriers during an episodic memory task, suggesting that these memory retrieval-related regions had to work harder to perform the task in the $T$ allele non-carriers. ${ }^{65,67}$ Moreover, ${ }^{18}$ F-FDG PET studies showed that cognitively normal KIBRA CC carriers had significantly lower CMRglc than KIBRA TT and $C T$ carriers in the posterior cingulate cortex. ${ }^{67}$

Although familial LOAD shows high heritability, which indicates genetic involvement, no wellreplicated susceptibility genes have been identified to date, with the exception of ApoE and SORL1. Studies are mostly hindered by the fact that LOAD is a common complex disorder of old age, with multi-factorial causes, including genetic and environmental components. Such aetiological complexity makes identification of LOAD-related genes challenging, whereas an 'endophenotype approach' may afford some advantage. ${ }^{69}$ Measuring phenotypic variation in pre-selected, homogeneous populations may expedite the search for specific genotypes.

\section{Family history of LOAD: Evidence for maternal transmission}

\section{Prevalence and risk}

Descriptively, two main variants of LOAD can be identified:

(1) LOAD with a familial component (LOFAD), which includes:

- Individuals with a parent, or both parents, affected with AD

- Individuals with first-degree family members other than the parents affected with AD (ie siblings)

- Individuals with second-degree family members affected with AD (ie aunts, uncles, grandparents)

- Combinations of the above.

(2) LOAD that appear to be sporadic in nature (LOSAD). These individuals are the first in their families to develop AD.

After advanced age, having a first-degree family history of LOAD is the most significant risk factor for developing AD among NL individuals. ${ }^{70,71}$ First-degree relatives of affected probands have a four- to tenfold higher risk for developing AD 
than the general population, with some variability depending on which family members are affected. $^{72-74}$ Children of affected parents are at especially high risk of $\mathrm{AD}$, as confirmed in multiethnic studies. ${ }^{73}$ Although having one parent with $\mathrm{AD}$ is per se a major risk factor for developing $\mathrm{AD}$ in the offspring, individuals with both parents affected appear to be at even greater risk for $\mathrm{AD}$, compared with those with one affected parent and with the general population. ${ }^{75,76}$ In general, individuals with LOFAD tend to develop dementia at younger ages than in LOSAD. ${ }^{77}$ Moreover, the age at onset of $\mathrm{AD}$ was lower in children with both parents with AD (mean age of onset 57 years, range 48-66) compared with children with one parent with AD (mean age of onset 60 years, range 50-80), and with those with no parents affected (mean age of onset 72 years, range $48-88) .^{75}$

Although there is mixed evidence for parent of origin gender effects in LOAD families, ${ }^{78,79}$ epidemiological studies have shown that maternal transmission of $\mathrm{AD}$ may have a greater impact on the offspring's health than paternal transmission. AD affects more women than men, with a relative risk of 1.5-3.6 across different ethnic groups, ${ }^{73}$ and maternal transmission is more frequent than paternal transmission of $\mathrm{AD} .{ }^{80}$ In $\mathrm{AD}$ patients with one affected parent, the ratio of mother-to-father affected is approximately 3:1 (Table 2). A review of the AD literature ${ }^{70,77,78,80,81}$ and data from the authors' current studies show that approximately 20 per cent of all LOAD cases are maternally inherited. Importantly, having an AD-affected mother was found to be associated with poorer cognitive performance in late life $^{82}$ and with a lower and more predictable age at onset of dementia in the offspring, compared with having an AD-affected father. ${ }^{77,80,83}$

There are no published studies that have examined whether cognitive performance deteriorates at younger ages in individuals with both parents affected, compared with those with one parent with AD. As individuals with both parents with AD are relatively rare (estimated prevalence is $3-5$ per cent of the total AD population) ${ }^{75}$ their clinical profile has been poorly studied.

At present, the absolute risk to the offspring associated with either an affected mother or father is not known. There is a paucity of longitudinal studies in pre-symptomatic AD. It is not known whether the prevalence of cognitive decline from normal to $\mathrm{AD}$ is higher in children of AD mothers compared with children of AD fathers, or with different family history. The genetic and pathological mechanisms through which a parental, especially maternal, history of AD confers increased susceptibility to the offspring remain largely unknown. Genetically mediated risk for a large proportion of LOAD cases is evident from the familial aggregation of $\mathrm{AD}$ and is only partially explained by the risk conferred by $A p o E \varepsilon 4$ alleles. The $A p o E \varepsilon 4$ genotype is found in fewer than 40 per cent of LOFAD cases, ${ }^{70}$ and not everyone with an $A p o E \varepsilon 4$ allele will develop AD. This indicates

Table 2. Prevalence of maternally vs paternally inherited late-onset Alzheimer's disease (AD)

\begin{tabular}{|c|c|c|c|c|c|c|}
\hline Reference & $\begin{array}{c}\text { AD } \\
\text { cases }\end{array}$ & $\begin{array}{c}\text { No } \\
\text { affected } \\
\text { parents }\end{array}$ & FH- & FHm & FHp & $\begin{array}{c}\text { Mother:father } \\
\text { ratio }\end{array}$ \\
\hline Duara et al. ${ }^{77}$ & 311 & 69 & $78 \%$ & $17 \%$ & $5 \%$ & $3.6: 1$ \\
\hline Farrer et al. ${ }^{70}$ & 251 & 61 & $76 \%$ & $16 \%$ & $8 \%$ & I.9:1 \\
\hline $\begin{array}{l}\text { Gomez-Tortosa } \\
\text { et al. }{ }^{80}\end{array}$ & 2594 & 817 & $68 \%$ & $23 \%$ & $9 \%$ & 2.6:1 \\
\hline
\end{tabular}

$\mathrm{FH}-=$ No family history of $\mathrm{AD} ; \mathrm{FHm}=$ maternal history of $\mathrm{AD} ; \mathrm{FHp}=$ paternal history of $\mathrm{AD}$. 
that other factors contribute to the aetiology and phenotypic expression of the disease. Thus far, these epidemiological and clinical findings have not been thoroughly characterised by the use of biomarkers, and LOFAD phenotypes have not been fully studied.

\section{Brain imaging studies of maternal history of $\mathrm{AD}$}

${ }^{18}$ F-FDG PET imaging studies have provided evidence for phenotypic differences between NL individuals with a maternal history of $\mathrm{AD}$ and those with a paternal family history. ${ }^{7,84}$ Examination of a group of over 50 50-80-year-old clinically normal and NL individuals showed that those subjects with an AD mother had reduced CMRglc compared with those with an AD father and with those with no parents affected (Figure 2). ${ }^{7}$ CMRglc reductions in the children of $\mathrm{AD}$ mothers involved the brain regions typically affected in clinical AD patients namely, the parieto-temporal, posterior cingulate/ precuneus, medial temporal and prefrontal cortices. No CMRglc differences were found between children of AD fathers and children of parents with no dementia. Moreover, CMRglc reductions in children of $\mathrm{AD}$ mothers remained significant after accounting for other possible risk factors for $\mathrm{AD}$, such as age, gender, education and $A p o E$ genotype. Importantly, hypometabolism was found within the group of maternal AD subjects irrespective of their ApoE status. ApoE $\varepsilon 4$ non-carriers with an AD mother showed CMRglc reductions compared with the $A p o E \varepsilon 4$ non-carriers with an $\mathrm{AD}$ father and those with no parents affected. These data show that CMRglc reductions in individuals with an AD mother occur independently of the subjects' ApoE genotype. ${ }^{7}$

Over a two-year follow-up interval, CMRglc reductions in NL subjects with an AD mother

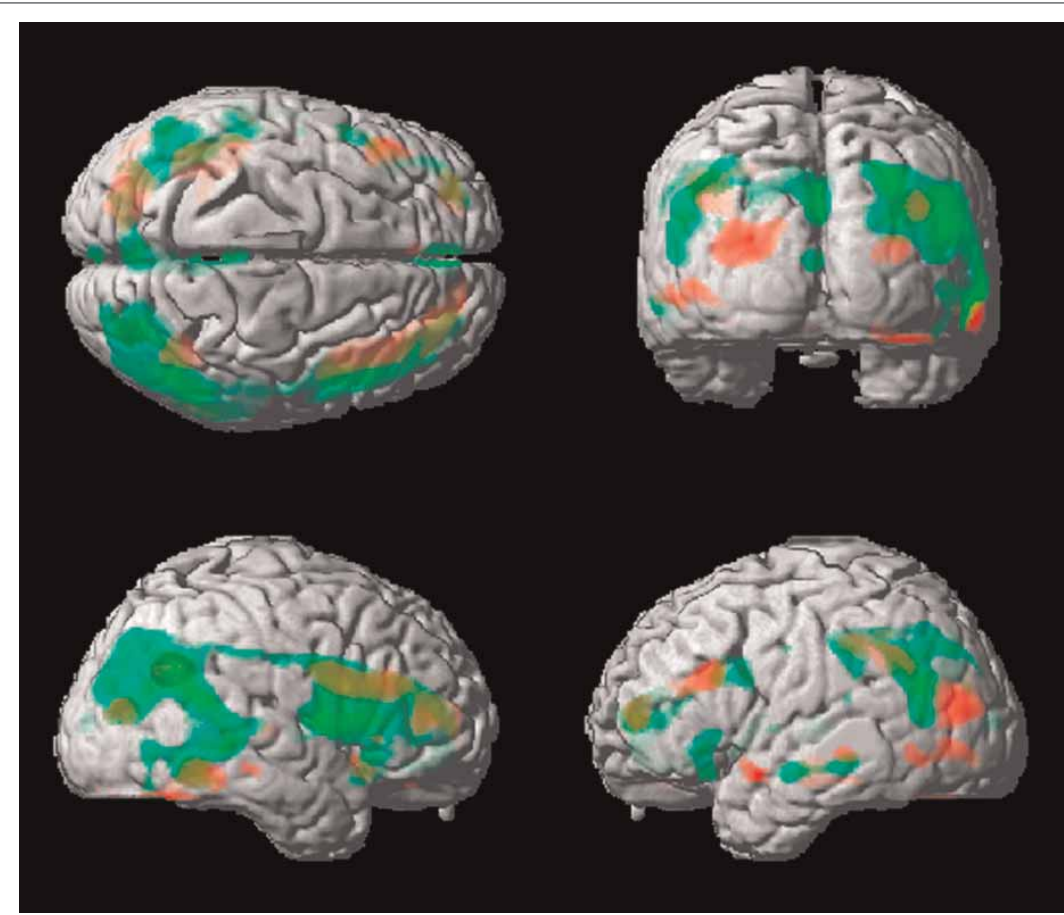

Figure 2. Statistical parametric maps showing reduced brain glucose metabolism in cognitively normal individuals with a maternal history of $A D(F H m)$ compared with those with a paternal history of $A D$ (FHp, in red) and with those with no family history of AD (FH-, in green). ${ }^{7}$ Brain regions showing hypometabolism in $\mathrm{FHm}$ compared with $\mathrm{FHp}$ and $\mathrm{FH}$ - include the inferior parietal lobes, lateral and inferior temporal cortex, posterior cingulate/precuneus and dorsolateral prefrontal cortex. These same brain regions are typically hypometabolic in clinical AD patients. Figure shows the superior, posterior, right and left lateral views of a three-dimensional volume-rendered MRI. 


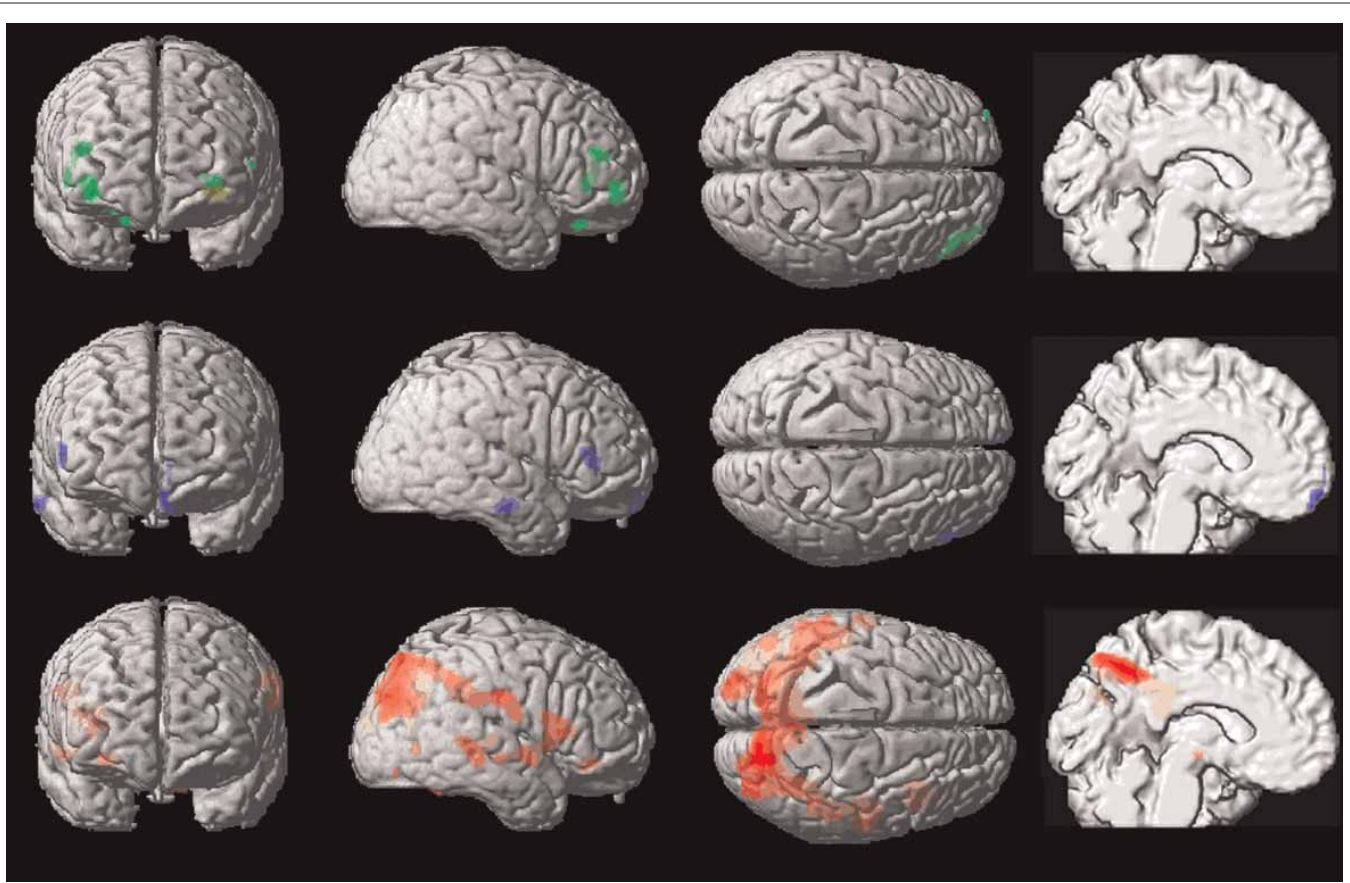

Figure 3. Statistical parametric maps showing CMRglc reductions over a two-year follow-up interval. Compared with the baseline, reduced follow-up CMRglc was restricted to the frontal cortices in normal subjects with no family history of AD (top row, in green) and in those with an AD father (middle row, in blue), whereas follow-up CMRglc was reduced in inferior parietal, lateral and inferior temporal, posterior cingulate/precuneus and prefrontal cortex in normal individuals with a maternal history of $A D$ (bottom row, in red). Figure shows the anterior, right lateral, superior and mid-sagittal views of a three-dimensional volume-rendered MRI.

were observed to be progressive. ${ }^{84}$ Longitudinally, subjects with an AD-affected mother showed progressive, bilateral CMRglc reductions in the posterior cingulate/precuneus, parieto-temporal and frontal cortices (Figure 3). By contrast, individuals with an AD-affected father and those with no parental history of AD showed longitudinal CMRglc reductions restricted to the frontal cortex, which is a typical effect of the ageing process. Within all these brain regions, CMRglc reductions over time were more severe in children of AD mothers compared with the other groups. ${ }^{84}$

This study included two subjects, one with an $\mathrm{AD}$ mother and the other with an $\mathrm{AD}$ father, whose AD parents were autopsied and given a postmortem diagnosis of AD. Examination of the individual ${ }^{18}$ F-FDG PET scans of these subjects showed that, compared with controls, the 68-year-old NL son of an AD-affected father did not show hypometabolism in any brain regions, whereas the 58-year-old NL daughter of an
AD-affected mother showed significant CMRglc reductions in $\mathrm{AD}$-vulnerable regions (Figure 4).

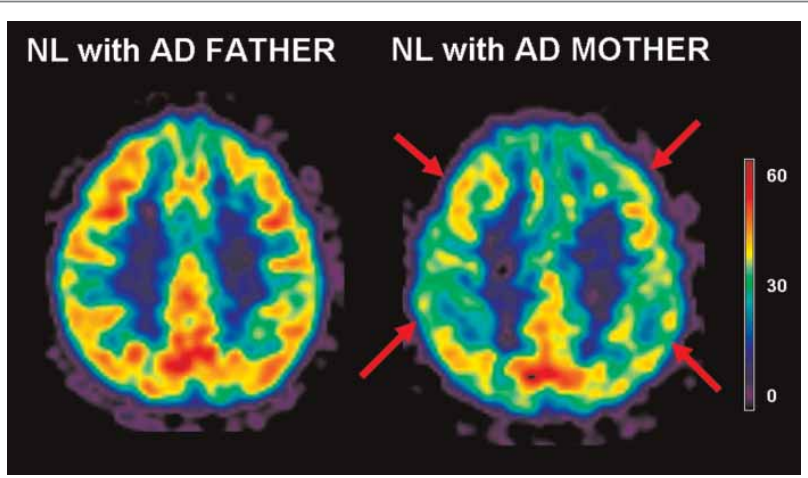

Figure 4. ${ }^{18}$ F-FDG PET scans of two cognitively normal (NL) individuals with postmortem-confirmed $A D$ parents. The ${ }^{18}$ F-FDG PET of the son of an AD father (left) shows no CMRglc abnormalities, while the ${ }^{18} \mathrm{~F}-\mathrm{FDG}$ PET of the daughter of an AD mother (right) shows areas of reduced CMRglc (indicated by arrows). ${ }^{7}$ CMRglc measures are represented on a colour-coded scale, ranging from 0 to $60 \mu \mathrm{mol}$ glucose/l00 g/ min (right side of figure). 
Of relevance to the above results, ${ }^{18}$ F-FDG PET studies in NL elderly individuals showed that CMRglc reductions in $\mathrm{AD}$ brain regions both predict and correlate with the decline from normal cognition to $\mathrm{MCI}$ and $\mathrm{AD} .{ }^{85,86}$ Reduced CMRglc at baseline accurately predicted future cognitive decline from normal to $\mathrm{AD}$ with 81 per cent accuracy, and from normal to MCI with 71 per cent accuracy. ${ }^{86}$ Over the study interval, the rate of CMRglc reduction was four times higher in the progressors to $\mathrm{AD}$, than in the non-progressors. ${ }^{86}$

The current observations suggest, and further longitudinal studies will be needed to confirm, that NL children of AD-affected mothers who have progressive CMRglc reductions in $\mathrm{AD}$ regions may be in the preclinical stages of AD. Clarification is also needed about whether an additive effect on regional hypometabolism occurs when both parents are $\mathrm{AD}$ affected. Finally, multi-modality imaging is warranted to assess the relationship between hypometabolism in children of $\mathrm{AD}$ mothers with $\mathrm{A} \beta$ and NFT pathology, or other biological markers of AD.

\section{Searching for genes involved in maternally inherited AD}

Classical genetic studies are challenging to perform in LOAD cases because the parents are usually not alive or the children are too young to manifest the phenotype of the disease. The above brain imaging findings in children of $\mathrm{AD}$ mothers provide a unique opportunity for studying and uncovering new genetically mediated risk factors for LOAD. Although Mendelian inheritance is not evident in LOFAD, the fact that children of affected individuals have an increased risk of developing the disease suggests a genetic component. Moreover, the fact that only children of affected mothers show CMRglc reductions consistent with $\mathrm{AD}$, suggests a maternally inherited predisposition to brain 'energetic' failure. The most likely genetic mechanisms to explain maternally inherited $\mathrm{AD}$ would appear to be (in alphabetical order):

- chromosome X-mediated transmission

- epigenetic imprinting

- mitochondrial DNA-mediated transmission
- sex-specific trinucleotide repeat expansionsmediated transmission,

\section{Chromosome X}

Chromosome $\mathrm{X}$-linked diseases are disorders that reflect the presence of defective genes on the $\mathrm{X}$ chromosome. The vast majority of X-linked diseases are characterised by recessive transmission with the following features: 1) males are more frequently affected than females because they are hemizygous and the gene defect is not balanced by a normal X chromosome; 2) females are rarely affected because they need to be homozygous for the defective gene to manifest the phenotype; 3) there is no male-to-male transmission; 4) transmission of the defective gene occurs from fathers to daughters, who become carriers; 5) males born to a carrier mother have a 50 per cent probability of inheriting the $\mathrm{X}$ chromosome carrying the defective gene. Classical examples of X-linked transmission are redgreen colour blindness and haemophilia A.

The presence of $\mathrm{X}$-linked inheritance could be a possible explanation for the higher prevalence of maternal transmission of $\mathrm{AD}$. As described above, the 'X-linked hypothesis' for a LOAD gene was supported by a recent genome-wide association study, which identified a strong association between LOAD and a mutation located on the PCDH11X gene on chromosome $\mathrm{X} .{ }^{64}$ Female homozygotes were at significantly increased risk for $\mathrm{AD}$ compared with female noncarriers, female heterozygotes and male hemizygotes. ${ }^{64}$ Moreover, female heterozygotes were at greater risk than female non-carriers, and male hemizygotes were at higher risk than male non-carriers. ${ }^{64}$

Although maternally inherited LOFAD and $\mathrm{X}$-linked diseases may share some characteristics, several properties of recessive $\mathrm{X}$-linked disorders do not apply to LOFAD. First, PCDH11X mutations were associated with higher risk in female homozygotes than male hemizygotes, which is contrary to what is usually found in X-linked recessive disorders. ${ }^{64}$ Secondly, there is no male-to-male transmission in X-linked inheritance, whereas father-to-son transmission has been reported in $\mathrm{AD} .{ }^{79,80}$ Although limited by sample size, in the authors' PET studies, there was no evidence for gender effects in the 
offspring of AD mothers. ${ }^{7}$ Males with an AD mother did not show more severe hypometabolism when compared with females with AD mothers. These results need to be confirmed with larger data sets specifically to examine the interaction between family history and gender on brain metabolism and other variables.

\section{Genomic imprinting}

Genomic imprinting is a genetic process by which certain genes are expressed in a parent-of-originspecific manner, which does not follow classical Mendelian inheritance. ${ }^{87}$ While expression of the majority of genes derives from both inherited copies (alleles) of the gene, a small proportion $(<1$ per cent) of genes are imprinted, which means that gene expression occurs from only one allele. In the majority of cases, one of the parental alleles is completely silenced and gene expression is monoallelic. This silencing mechanism is known to involve epigenetic marking by allele-specific DNA methylation and/or histone modifications. ${ }^{88}$ Differential epigenetic marking of the parental chromosomes results in differential reading by the transcriptional machinery and, as a consequence, gene expression is predominantly from one parental allele. For example, the gene encoding insulin-like growth factor 2 (IGF2/Igf2) is only expressed from the allele inherited from the father.

For a gene that is normally imprinted with paternal silencing, a mutation in the maternal copy of the gene will result in disease, while a mutation in the paternal copy will have no effect, and vice versa. According to the parental conflict hypothesis, paternal imprinting appears to be growth promoting, while maternal imprinting would be growth limiting. ${ }^{89}$ More specifically, the paternal genome maximises extraction of maternal resources for the benefit of the paternal offspring, at the expense of offspring from other embryos, possibly from different fathers. By contrast, the maternal genome limits nutrient provision to each individual embryo to distribute resources equally among her offspring, independent of the fathers. Irrespective of parental origin, the majority of imprinted genes in mammals have roles in the control of embryonic growth and development, including development of the placenta, and in postnatal development, with roles affecting suckling and metabolism. ${ }^{87}$

Imprinted genes are susceptibility targets for numerous human pathologies because their functional haploid state enables a single genomic or epigenomic change to dysregulate their function. Recent evidence has highlighted the role of genetic imprinting on brain function for PraderWilli and Angelman syndromes, as well as more common disorders like diabetes, obesity, breast cancer, autism, bipolar disorder, Tourette's syndrome, epilepsy and even AD. ${ }^{87}$ Maternal imprinting may be a genetic mechanism responsible for the increased maternal inheritance in LOFAD cases. Some reports showed that the methylation process involved in imprinting is altered in $\mathrm{AD}$ patients, compared with controls. ${ }^{90}$ A genomewide screening of AD families reported a linkage between LOAD and a region close to the centromere of chromosome $10 \mathrm{q}$ only in families with an AD affected mother. ${ }^{91}$ While these findings suggest imprinting, ${ }^{91}$ there is no clear evidence for the existence of imprinted genes in AD families on chromosome 10 or on other chromosomes.

With respect to our ${ }^{18}$ F-FDG PET findings, hypometabolism in children of AD mothers suggests 'metabolic imprinting'. Metabolic imprinting refers to the epigenetic programming of metabolism during the prenatal and neonatal periods and may have long-term consequences for health. ${ }^{87}$ For example, glucocorticoid exposure in late pregnancy and foetal under-nutrition have been linked to increased risk for cardiovascular disease, obesity, type two diabetes and hypertension. ${ }^{87,92}$ In animal studies, most of the 80 known imprinted genes are expressed in the placenta and influence maternofoetal nutrient transfer during gestation and placental growth. ${ }^{93}$ Maternal nutrition itself was shown to have a role in hormonal imprinting. The presence of harmful substances or the lack of important substrates in the mother's diet can induce adult-onset disease in the progeny. ${ }^{92}$ Little is known about hormonal imprinting of the brain, however, and there are currently no studies that have examined imprinting as a source of metabolic dysregulation in AD. 
Finally, there is evidence from animal models for $\mathrm{X}$ chromosome-linked imprinted genes that could influence sexually dimorphic neurobiology. ${ }^{94}$ The $\mathrm{X}$ chromosome is enriched for genes affecting neurodevelopment. Investigations into imprinted genes on chromosome $\mathrm{X}$ may provide insights into why women and men apparently show differential vulnerability to $\mathrm{AD} .{ }^{94}$ As with chromosome $\mathrm{X}$ mutations, findings of gender effects on brain deficits would support a role for this mechanism in AD.

\section{Mitochondrial DNA}

Mitochondrial disorders are entirely maternally inherited in humans and are characterised by variable phenotypic expression. Male and female progeny are equally likely to receive mutant maternal mitochondrial DNA (mtDNA). The same mtDNA mutation may affect different organs in different individuals, and may lead to minor or severe defects. The prominent role of mitochondrial function in regulating molecular processes involved in glucose metabolism suggests the possibility that mtDNA mutations, with resulting mitochondrial dysfunction and oxidative damage, may be involved in the pathophysiology of AD. Mitochondrial dysfunction may also be responsible for alterations in glucose metabolism in AD brain tissue ${ }^{95}$ and the selective metabolic impairment in children of $\mathrm{AD}$ mothers. The fact that mtDNA is exclusively maternally inherited in humans lends support to this hypothesis.

Human mtDNA is a 16,569-kilobase circular, double-stranded molecule, which contains 37 genes: two rRNA genes, 22 tRNA genes and 13 structural genes that encode electron transport chain (ETC) subunits and the mitochondrial ATP synthase. While most ETC proteins (ie complex II, coenzyme Q and cytochrome c) are encoded by nuclear DNA, mtDNA encodes the catalytic components of complexes I, III, IV and V, all of which are essential for maintaining physiological oxidative phosphorylation (OXPHOS). OXPHOS is the process that accounts for the high ATP yield by the cells, and is essential to the maintenance of cellular homeostasis and function.

The brain has high energy requirements, contains a large number of mitochondria and is therefore highly susceptible to reductions in aerobic metabolism. Deficient energy metabolism may change the overall oxidative microenvironment for neurones during the pathogenesis of $\mathrm{AD}$, rendering synapses more vulnerable to $A \beta$ and tau pathology.

Mutations of mtDNA lead to a number of illnesses caused by inadequate energy supply that mostly present as neuromuscular diseases. ${ }^{96}$ These range from exercise intolerance to diseases with severe body-wide impact, such as the mitochondrial encephalopathy, lactic acidosis and stroke syndrome (MELAS - a rare form of dementia associated with seizures); headaches; muscle disease and stroke-induced paralysis; and Kearns-Sayre syndrome (KSS), which causes a person to lose full function of their heart, eye and muscle movements. In addition to mitochondrial myopathies, other mtDNA diseases include diabetes mellitus and deafness (DAD), Leber's hereditary optic neuropathy (LHON) and Leigh syndrome (see below).

For more than 15 years, evidence has accumulated that $\mathrm{AD}$ is associated with mitochondrial dysfunction, oxidative stress and increased reactive oxygen species (ROS) production. At postmortem, extensive oxidative stress is found in AD brains, in which basically all cellular macromolecules (protein, DNA, lipids) are found in an oxidised form. ${ }^{97-99}$ A specific mitochondrial defect demonstrated in $\mathrm{AD}$ is reduced cytochrome oxidase (COX) activity in brain regions showing neuronal loss. ${ }^{100-104}$ COX (ETC complex IV) is the mitochondrial enzyme responsible for the activation of oxygen for aerobic energy metabolism and is critically tied to ATP production in mitochondria. ${ }^{105,106}$ COX is localised primarily in mitochondria near excitatory synapses in neuronal dendrites, and its activity is tightly linked to the regulation of CMRglc in the synapses. ${ }^{105}$ Preferentially reduced COX activity in $\mathrm{AD}$ was shown in several in vivo studies of blood platelets ${ }^{107-112}$ and fibroblasts. ${ }^{100,111,113}$ Platelet mitochondria COX activity was also significantly reduced in MCI patients compared with controls. ${ }^{112}$ Overall, these studies provide evidence for peripheral abnormalities in COX activity and increased oxidative stress in such cells as blood platelets and fibroblasts, which are non-degenerating 
tissues and should not be affected by brain pathology. This suggests that COX reductions may not be simply a secondary or epiphenomenal consequence of neurodegeneration, but may instead represent a systemic perturbation in AD.

Nonetheless, mtDNA studies in AD have provided non-conclusive, and often conflicting, results. Studies that investigated the role of mtDNA mutations in AD have used three main approaches: cytoplasmic hybrid (cybrid) analyses, case-control mutation identification studies and mitochondrial haplogroup association studies. Studies of cybrid cells provide direct evidence for mtDNA involvement in the metabolic abnormalities characteristic of AD (Figure 5). Cybrids are obtained by mixing mtDNA from affected patients' platelets with cell lines depleted of their own endogenous mtDNA, resulting in cell lines containing mtDNA from the patient. ${ }^{115}$ These cell lines expand under standard culture conditions, and their biochemical assessment allows investigators to evaluate parameters directly or indirectly referable to mitochondria and presumably the mtDNA they carry. ${ }^{116}$ Cybrid data in $\mathrm{AD}$ show that mtDNA at least partly accounts for impaired metabolism and increased oxidative stress in AD, as reflected in increased ROS production. Defects in mitochondrial respiratory enzymes, particularly affecting COX activity, increase changes in calcium homeostasis, decrease ATP production, enhance $A \beta$ toxicity and vastly increase the percentage of morphologically abnormal mitochondria. ${ }^{117-120}$

In addition to cybrid studies, several case-control studies using mutation identification and

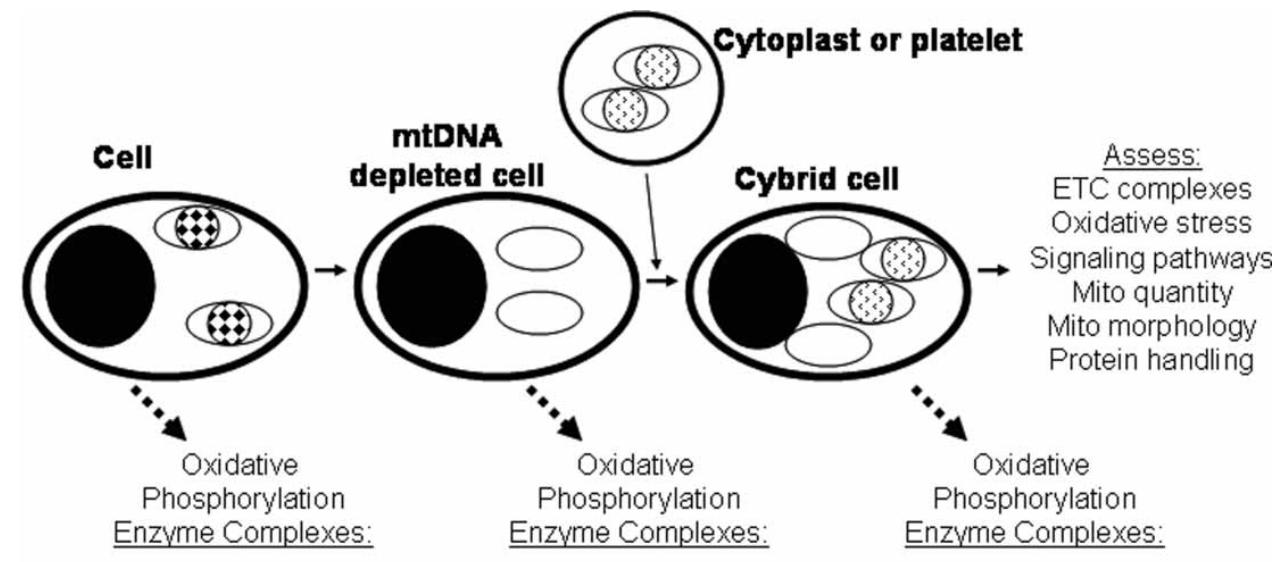

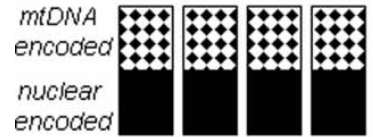

encoded

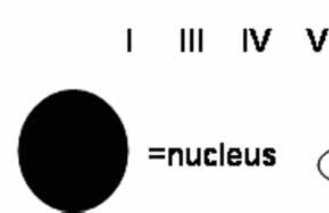

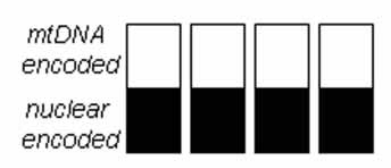

I III IV V

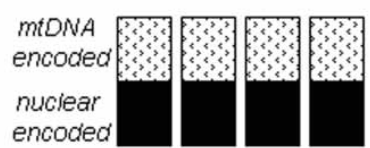

I III IV V

Figure 5. The cybrid technique (adapted from Kish et al. ${ }^{1 / 4}$ ). The procedure involves obtaining mtDNA from persons with and without disease. Usually, platelets are used as the mtDNA donor tissue, since platelets are easily obtained through standard phlebotomy, are easy to isolate through centrifugation and lack nuclei. Mixing platelets with cell lines depleted of their own endogenous mtDNA allows exchange of platelet and cell line materials, which results in cell lines containing mtDNA from the individual platelet donors. These cell lines expand under standard culture conditions, and their biochemical assessment allows investigators to evaluate parameters directly or indirectly referable to mitochondria and the mtDNA they carry. Differences in mtDNA lead to differences in the mtDNA-encoded subunits of oxidative phosphorylation complexes I, III, IV and V. Functional differences between cybrid cell lines should reflect differences in mtDNA that cause changes in these enzyme complexes. 
mitochondrial haplogroup association studies suggest that maternally inherited mutations of mtDNA may play a pathogenic role in AD (Table 3). Despite the observation of mtDNA mutations in AD versus controls, and of associations observed between specific haplotypes and an increased risk for $\mathrm{AD}$, however, many of these exploratory findings were not confirmed by subsequent studies. ${ }^{95}$ Therefore, the role of mitochondrial genome changes in the pathogenesis of ageing and AD needs further clarification, and it is possible that the maternally inherited metabolic endophenotype may be helpful for such investigations.

Table 3. Mitochondrial DNA mutations and haplotypes associated with late-onset $A D$

\begin{tabular}{|c|c|c|c|}
\hline Approach & Finding & Positive findings & $\begin{array}{l}\text { Negative } \\
\text { findings }\end{array}$ \\
\hline \multirow[t]{3}{*}{$\begin{array}{l}\text { Case-control } \\
\text { mutation } \\
\text { identification }\end{array}$} & $\begin{array}{l}\text { TI46G, } \\
\text { TI95C, } \\
\text { TI52C, } \\
\text { AI89G, } \\
\text { T4I4G }\end{array}$ & $\begin{array}{l}\text { Increased AD } \\
\text { risk }^{|2|}\end{array}$ & $\begin{array}{l}\text { No mutation } \\
\text { found }^{122}\end{array}$ \\
\hline & $\begin{array}{l}4977 \text { bp } \\
\text { deletion }\end{array}$ & $\begin{array}{l}\text { More frequent in } \\
\text { AD patients }\end{array}$ & \\
\hline & A4336G & $\begin{array}{l}\text { More frequent in } \\
A D \text { patients } \\
\text { 124,125 }\end{array}$ & $\begin{array}{l}\text { No } \\
\text { association } \\
\text { with } A D^{126}\end{array}$ \\
\hline \multirow[t]{4}{*}{$\begin{array}{l}\text { Haplogroup } \\
\text { association }\end{array}$} & $\mathrm{K}, \mathrm{U}$ & $\begin{array}{l}\text { Decreased risk of } \\
A D \text {, neutralising } \\
\text { the effect of } A p o E \\
\text { genotype }^{127}\end{array}$ & $\begin{array}{l}\text { No effect of } \\
K \\
\text { haplogroup } \\
\text { in } A D^{128}\end{array}$ \\
\hline & $U$ & $\begin{array}{l}\text { Increased risk in } \\
\text { males, decreased } \\
\text { risk in females }{ }^{128}\end{array}$ & \\
\hline & $\mathrm{J}$ & $\begin{array}{l}\text { Increased in AD } \\
\text { patients in a } \\
\text { French-Canadian } \\
\text { population }\end{array}$ & $\begin{array}{l}\text { No AD } \\
\text { haplogroup } \\
\text { association } \\
\text { in US } \\
\text { population }^{122}\end{array}$ \\
\hline & $\mathrm{T}$ & $\begin{array}{l}\text { Decreased AD risk } \\
\text { in a French- } \\
\text { Canadian } \\
\text { population }^{129}\end{array}$ & $\begin{array}{l}\text { No AD } \\
\text { haplogroup } \\
\text { association } \\
\text { in US } \\
\text { population }^{122}\end{array}$ \\
\hline
\end{tabular}

$\mathrm{bp}=$ base pair

\section{Sex-specific trinucleotide repeat expansions}

Trinucleotide repeat disorders (TRD) are a class of molecular diseases characterised by the presence of unstable and abnormal expansions of DNA triplets (trinucleotides). Mutations present as a subset of unstable repeats that occur throughout the genomic sequence, resulting in chromosomal instability. Generally, the larger the expansions, the more likely they are to cause disease or increase the severity of disease. This property results in the phenomenon of genetic anticipation, as is evident in TRDs, in which there is a tendency for age of onset to decrease and severity of symptoms to increase through successive generations of an affected family, due to the expansion of these repeats. ${ }^{130}$ Large increases or expansions in the number of trinucleotide tandem repeats are involved in a number of inherited neurodegenerative conditions, which appear to be specific to the gender of the transmitting parent. For example, in Huntington's disease there is an increased number of CAG repeats, and this condition is preferentially paternally inherited. ${ }^{131}$ Some neurological TRDs show a preferential maternal transmission, such as fragile X syndrome, ${ }^{132}$ Friedreich ataxia, ${ }^{133}$ spinocerebellar ataxia type $8^{63}$ and myotonic dystrophy. ${ }^{134}$ Trinucleotide expansions may also be involved in some cases of frontotemporal dementia, although results are not conclusive. ${ }^{135,136}$ There is currently no evidence for trinucleotide repeat expansions in AD.

\section{Maternal transmission in neurological disorders other than AD}

A wide spectrum of diseases has been associated with preferential maternal transmission resulting from various genetic mechanisms. Parkinson's disease has more common features with AD than the other disorders, and is therefore presented separately and in more detail.

\section{Parkinson's disease}

Parkinsonian syndromes are movement disorders that can be divided into idiopathic Parkinson's 
disease (PD), multiple system atrophy (MSA) and parkinsonian syndromes (PDS) secondary to other conditions or exogenous agents. While MSA and PDS are purely movement disorders, it is not uncommon for PD patients to develop dementia. ${ }^{137} \mathrm{PD}$ is a neurodegenerative disease that typically impairs motor skills, speech and other cognitive functions, and is characterised by muscle rigidity, tremor, bradykinesia (ie slowing of physical movement) and akinesia (ie loss of physical movement) in severe cases. ${ }^{138}$ The primary symptoms are the result of decreased stimulation of the motor cortex due to degeneration of dopaminergic neurones in the substantia nigra.

As in $\mathrm{AD}$, epidemiological data indicate that the risk of developing PD is greater for a person whose mother was affected by the disease than for the offspring of an affected father. ${ }^{139,140}$ Moreover, only maternal transmission of PD was found to affect the age at onset in affected families. ${ }^{141}$

While there is no evidence for chromosome $\mathrm{X}$ mutations or imprinting in PD, it is now widely accepted that inherited or somatic mtDNA variations contribute to the aetiology of PD (Table 4). Mitochondrial damage in PD results in ETC complex I deficits (instead of the ETC complex IV deficits typically observed in AD) ${ }^{95} \mathrm{PD}$ was one of the first identified neurodegenerative mitochondriopathies. In the early 1980s, a toxin-induced subacute parkinsonism syndrome reminiscent of idiopathic PD was described. ${ }^{148}$ The responsible toxin, 1-methyl-4-phenyl-1,2,3,6-tetrahydropyridine (MPTP), was next shown to inhibit ETC complex I. MPTP administration to laboratory animals has been found to destroy the substantia nigra and even induced Lewy body formation in aged chimpanzees. ${ }^{148}$ Subsequent research revealed that other complex I inhibitors induce a parkinsonism phenotype, loss of dopaminergic nigral neurones and histological changes similar to those seen in human PD. ${ }^{149}$ Complex I enzymatic lesions, but not other ETC enzymes, are found in PD patients in both the substantia nigra and muscle, ${ }^{150}$ which may be due to mtDNA mutations. ${ }^{151-153}$
Table 4. Mitochondrial DNA mutations and haplotypes associated with Parkinson's disease (PD)

\begin{tabular}{|c|c|c|}
\hline $\begin{array}{l}\text { mtDNA } \\
\text { haplogroup or } \\
\text { mutation }\end{array}$ & $\begin{array}{l}\text { Hypothesised } \\
\text { role }\end{array}$ & Reference \\
\hline Haplogroup J, K & Lower PD risk & Van der Walt et al. ${ }^{142}$ \\
\hline $\begin{array}{l}\text { UKJT haplogroup } \\
\text { supercluster }\end{array}$ & Lower PD risk & Pyle et al. ${ }^{143}$ \\
\hline $\begin{array}{l}\text { JTIWX } \\
\text { haplogroup } \\
\text { supercluster }\end{array}$ & $\begin{array}{l}\text { Higher PD and } \\
\text { PD with } \\
\text { dementia risk }\end{array}$ & Autere et al. ${ }^{144}$ \\
\hline Haplogroup I, J, K & $\begin{array}{l}\text { Decreased risk } \\
\text { for PD but } \\
\text { increased risk } \\
\text { for PD with } \\
\text { dementia }\end{array}$ & Autere et al. ${ }^{144}$ \\
\hline $\begin{array}{l}\text { mtDNA } \\
\text { mutation: } \\
\text { I0398G (J, K, I } \\
\text { haplogroups) }\end{array}$ & Lower PD risk & $\begin{array}{l}\text { Van der Walt et al.; }{ }^{142} \\
\text { Autere et al. }\end{array}$ \\
\hline $\begin{array}{l}\text { mtDNA } \\
\text { mutation: } 9055 \mathrm{~A}\end{array}$ & $\begin{array}{l}\text { Lower PD risk } \\
\text { (only in women) }\end{array}$ & Van der Walt et al. ${ }^{142}$ \\
\hline $\begin{array}{l}\text { mtDNA } \\
\text { mutation: } 4216 C \\
\text { (ND/ gene) }\end{array}$ & $\begin{array}{l}\text { Increased PD } \\
\text { risk }\end{array}$ & Kirchner et al. ${ }^{145}$ \\
\hline $\begin{array}{l}\text { mtDNA } \\
\text { mutation: } 4216 C \\
\text { (ND/ gene) }\end{array}$ & $\begin{array}{l}\text { No difference } \\
\text { observed }\end{array}$ & Huerta et al. ${ }^{146}$ \\
\hline $\begin{array}{l}\text { mtDNA } \\
\text { mutation: } 4336 \\
\text { (tRNA }\end{array}$ & $\begin{array}{l}\text { More frequent in } \\
\text { PD patients }\end{array}$ & Tan et al. ${ }^{147}$ \\
\hline
\end{tabular}

The cybrid technique has provided an effective strategy for probing the role of mtDNA in PD as well as AD subjects. ${ }^{154}$ To summarise the results of PD cybrid studies, transferring PD platelet mitochondria to mtDNA-depleted human cells produced cell lines with reduced complex I activity, elevated peroxide levels, increased antioxidant enzyme activities, altered calcium and signalling pathway homeostasis and cytoplasmic protein aggregations that contain $\alpha$ synuclein. ${ }^{155}$ Of great relevance to the imaging findings in children of AD mothers, a cybrid study in PD examined ETC 
activity of multiple members over three generations affected with PD through exclusively maternal lines and compared them with those of paternally descended family members. ${ }^{156}$ Compared with the cybrid lines containing mtDNA from paternal descendants, cybrid lines containing mtDNA from maternal descendants had lower complex I activity, increased ROS production and more abnormal mitochondrial morphologic features. ${ }^{156}$ These findings were present in cybrid lines containing mtDNA from maternal descendants affected with PD as well as in asymptomatic young maternal descendants. $^{156}$ These data indicate that mtDNA mutations may be a primary genetic deficit in maternally inherited PD. There are currently no published imaging studies that have compared symptomatic or pre-symptomatic children of PD mothers with children of PD fathers.

\section{Maternal transmission of other neurological disorders}

Several neurological disorders show preferential maternal inheritance (Table 5). Overall, these maternally inherited disorders are characterised by phenotypic manifestation mainly in infancy or early adulthood. Disorders due to mtDNA mutations are more frequent and typically present as multisystemic diseases. None of these disorders resemble the clinical phenotype of $\mathrm{AD}$; however, some reports have suggested a link between $A D$ and maternally inherited neurological disorders. For example, mitochondrial haplogroup $\mathrm{J}$ has been associated with increased risk of $\mathrm{AD}$, MELAS and LHON. $^{168}$

\section{Conclusions, implications and future challenges}

Clinical and epidemiological studies show that maternally inherited AD may account for over 20 per cent of all LOAD cases, and children of AD mothers are at higher risk for developing $\mathrm{AD}$ than children of AD fathers. Brain ${ }^{18}$ F-FDG PET studies have shown that children of AD mothers are at risk of developing brain hypometabolism early in life, which may partially explain the increased predisposition. Genetic mechanisms involved with maternally inherited metabolic deficits in AD are under investigation.

Metabolic deficits in normal individuals with a maternal history of AD represent a unique opportunity for the initiation of $\mathrm{AD}$ therapies and general preventive methods years - and possibly decades - prior to the onset of the clinical disease, presumably well before significant neuronal loss occurs. CMRglc reductions in asymptomatic children of AD mothers can ideally be used as a surrogate marker of $\mathrm{AD}$ progression in clinical trials to test the potential of preventive treatments for AD. ${ }^{51}$ Moreover, they could be used as a biomarker of $\mathrm{AD}$ in quantitative trait genetic analysis, instead of standard case-control studies, to examine the genes involved in maternal transmission in AD. The combination of imaging and custom-tailored genetics may help to clarify whether changes in the nuclear or mitochondrial genome and transcriptome account for pathogenic ageing and AD.

It is important to underline that the genes involved in maternally inherited AD do not follow an autosomal dominant pattern of transmission, and penetrance does not appear to be high, as many children of mothers with AD do not develop the disease. Although the presence of a maternal history of AD indicates that children may be at higher risk, it does not imply that the children are carriers of the hypothesised mutated gene or allelic variant. The maternal link may not be the only cause of $\mathrm{AD}$ in the children, who may develop sporadic $\mathrm{AD}$, or $\mathrm{AD}$ linked to non-maternal genetic risk factors for LOAD, however. All of these non-maternally inherited genetic or sporadic causes of AD may also lead individuals to develop a metabolic pattern comparable with that described in our studies. Moreover, the AD mothers may have sporadic LOAD, which would probably not be inherited by the children. In this case, multigenerational studies may help to identify individuals with a definite history of maternally inherited AD spanning two or more generations.

Finally, evidence for early metabolic deficits in the children of AD mothers suggests that this form of LOFAD may be both a neurodevelopmental and 
Table 5. Medical and neurological disorders with known or suspected maternal inheritance

\begin{tabular}{|c|c|c|c|}
\hline Disorder & Mechanism & Clinical phenotype & Reference \\
\hline $\begin{array}{l}\text { Kearns-Sayre } \\
\text { syndrome }\end{array}$ & $\begin{array}{l}\text { mtDNA deletions present at } \\
\text { levels up to } 80 \% \text { of total } \\
\text { mtDNA. The most frequent is } \\
4977 \text { bp deletion }\end{array}$ & $\begin{array}{l}\text { Paralysis of the extraocular } \\
\text { muscles, pigmentary retinopathy, } \\
\text { heart block, cerebellar ataxia and } \\
\text { elevated CSF proteins }\end{array}$ & Maceluch et al. ${ }^{157}$ \\
\hline $\begin{array}{l}\text { Mitochondrial } \\
\text { encephalomyopathy, } \\
\text { lactic acidosis and } \\
\text { stroke-like episodes } \\
\text { (MELAS) }\end{array}$ & $\begin{array}{l}\text { mtDNA mutation: A3243G } \\
\left(\text { (tRNA }^{\text {Leu(UUR) }}\right)\end{array}$ & $\begin{array}{l}\text { Children and young adults. } \\
\text { Recurrent vomiting, migraine-like } \\
\text { headache, stroke-like episodes } \\
\text { causing cortical blindness, } \\
\text { hemiparesis or hemianopia }\end{array}$ & Thambisetty et al. ${ }^{158}$ \\
\hline $\begin{array}{l}\text { Myoclonic epilepsy with } \\
\text { ragged red fibres } \\
\text { (MERRF) }\end{array}$ & $\begin{array}{l}\text { mtDNA mutation: A8344G, } \\
\text { T8356C, G8363A (tRNA }{ }^{\text {Lys }} \text { ) }\end{array}$ & $\begin{array}{l}\text { Myclonus, seizures, } \\
\text { mitochondrial myopathy and } \\
\text { cerebellar ataxia; less common } \\
\text { signs can include dementia, } \\
\text { hearing loss, peripheral } \\
\text { neuropathy and multiple lipomas }\end{array}$ & DiMauro et al. ${ }^{159}$ \\
\hline $\begin{array}{l}\text { Neuropathy, ataxia, } \\
\text { retinitis pigmentosa } \\
\text { (NARP) }\end{array}$ & $\begin{array}{l}\text { mtDNA mutation: T8993G, } \\
\text { T8993C (nt-8993 at the } \\
\text { ATPase6 gene) }\end{array}$ & $\begin{array}{l}\text { Retinitis pigmentosa, dementia, } \\
\text { seizures, ataxia, proximal } \\
\text { weakness and sensory } \\
\text { neuropathy }\end{array}$ & Holt et al. ${ }^{160}$ \\
\hline $\begin{array}{l}\text { Maternally inherited } \\
\text { Leigh syndrome (MILS) }\end{array}$ & $\begin{array}{l}\text { mtDNA mutation: T8993G, } \\
\text { T8993C (nt-8993 at the } \\
\text { ATPase6 gene) }\end{array}$ & $\begin{array}{l}\text { Symmetrical lesions in the basal } \\
\text { ganglia and the brainstem }\end{array}$ & Holt et al. ${ }^{160}$ \\
\hline $\begin{array}{l}\text { Leber's hereditary optic } \\
\text { neuropathy (LHON) }\end{array}$ & $\begin{array}{l}\text { mtDNA mutation: GII778A } \\
\text { (ND4 gene), } \\
\text { G3460A (NDI gene), } \\
\text { TI4484C (ND6 gene) }\end{array}$ & $\begin{array}{l}\text { Acute or subacute loss of vision } \\
\text { in young adults due to bilaterally } \\
\text { optic neuropathy }\end{array}$ & Yen et al. ${ }^{161}$ \\
\hline $\begin{array}{l}\text { Progressive external } \\
\text { ophthalmoplegia (PEO) }\end{array}$ & $\begin{array}{l}\text { mtDNA mutation in genes } \\
\text { encoding tRNA }{ }^{\text {Leu }}, \text { tRNA }^{\text {lle }} \text { and } \\
\text { tRNA }\end{array}$ & $\begin{array}{l}\text { Progressive paralysis of the } \\
\text { extraocular muscles }\end{array}$ & Silvestri et al. ${ }^{162}$ \\
\hline $\begin{array}{l}\text { Maternally inherited } \\
\text { diabetes and deafness } \\
\text { (MIDD) }\end{array}$ & $\begin{array}{l}\text { mtDNA mutation: } A 3243 G \\
\left(\text { tRNA }^{\text {Leu }}\right)\end{array}$ & $\begin{array}{l}\text { Impaired glucose tolerance } \\
\text { (IGT)/diabetes, sensorineural } \\
\text { deafness. Other symptoms are: } \\
\text { macular pattern dystrophy ( } 86 \%) \text {, } \\
\text { myopathy (43\%), cardiomyopathy } \\
\text { (I5\%), neurological abnormalities } \\
\text { and neuropsychiatric symptoms } \\
\text { (I8\%), gastrointestinal and renal } \\
\text { dysfunction }\end{array}$ & Hosszufalusi et al. ${ }^{163}$ \\
\hline $\begin{array}{l}\text { Juvenile myoclonic } \\
\text { epilepsy }\end{array}$ & $\begin{array}{l}\text { Genomic imprinting: EJM-I } \\
\text { (chromosome 6) }\end{array}$ & Seizures & Pal et al. ${ }^{164}$ \\
\hline Tourette's syndrome & Genomic imprinting & $\begin{array}{l}\text { Multiple physical (motor) and } \\
\text { vocal (phonic) tics }\end{array}$ & Eapen et al. ${ }^{165}$ \\
\hline
\end{tabular}


Table 5. Continued

\begin{tabular}{|c|c|c|c|}
\hline Disorder & Mechanism & Clinical phenotype & Reference \\
\hline Angelman syndrome & $\begin{array}{l}\text { Genomic imprinting } \\
\text { (chromosome 15) }\end{array}$ & $\begin{array}{l}\text { Intellectual and developmental } \\
\text { delay, sleep disturbance, seizures, } \\
\text { jerky movements, frequent } \\
\text { laughter or smiling and usually a } \\
\text { happy demeanour }\end{array}$ & $\begin{array}{l}\text { Horsthemke } \\
\text { et al. }{ }^{166}\end{array}$ \\
\hline Autism & $\begin{array}{l}\text { Genomic imprinting } \\
\text { (chromosome 15) }\end{array}$ & Autism & Cook et al. ${ }^{167}$ \\
\hline Fragile $X$ syndrome & $\begin{array}{l}\text { Unstable expansions of a CGG } \\
\text { trinucleotide repeat located in } \\
\text { the first exon } \\
\text { (non-protein-coding) of the } \\
\text { FMRI gene (for fragile } X \text { mental } \\
\text { retardation) }\end{array}$ & $\begin{array}{l}\text { Stereotypic movements and } \\
\text { atypical social development up } \\
\text { to autism. Cluttered or nervous } \\
\text { speech; intellectual disability } \\
\text { (from mild to severe); elongated } \\
\text { face, large or protruding ears, flat } \\
\text { feet and low muscle tone }\end{array}$ & Mandel et al. ${ }^{132}$ \\
\hline Friedreich ataxia & $\begin{array}{l}\text { GAA repeat expansion } \\
\text { (chromosome 9) }\end{array}$ & $\begin{array}{l}\text { Ataxia, gait disturbance, speech } \\
\text { problems, heart disease } \\
\text { (in some cases) }\end{array}$ & La Pean et al. ${ }^{133}$ \\
\hline Myotonic dystrophy & CTG repeat expansion & $\begin{array}{l}\text { Muscle weakness, cataract, } \\
\text { myotonia, infertility }\end{array}$ & Botta et al. ${ }^{134}$ \\
\hline
\end{tabular}

$\mathrm{bP}=$ base pair; $\mathrm{CSF}=$ cerebrospinal fluid

a neurodegenerative disorder. Several studies have hypothesised a direct relationship between early development and late-life neurodegeneration based on similarities between APP and the Notch protein, which is critically involved in central and peripheral nervous system development and, like APP, is cleaved by presenilins. ${ }^{169,170}$ APP was shown to be a ligand for death receptor 6 (DR6), which triggers neurodegeneration during embryonal development. ${ }^{171}$ In particular, in NGF knockout mice, trophic deprivation led to the cleavage of surface APP by beta-secretase, with generation of an N-APP fragment which bound DR6, triggering caspase activation and degeneration of both neuronal cell bodies (via caspase 3) and axons (via caspase 6). ${ }^{171}$ Therefore, the pathological process in AD may begin as early as at birth, as a result of lack of trophic support and nutrients to the embryo. This observation suggests a role for metabolic imprinting in neurodegeneration in $\mathrm{AD}$, which can only be maternally inherited.

In conclusion, integration of information from genetic, transcriptomic and proteomic studies, and from in vivo biomarkers, will greatly advance our understanding of the causes of $\mathrm{AD}$, improve our ability to establish an early diagnosis, help to define disease subgroups and, ultimately, help to develop preventive treatments based on individuals' own pathophysiology.

\section{Acknowledgments}

This study was supported by NIH/NIA AG032554, AG13616, AG08051 and AG022407, and an anonymous foundation.

\section{References}

1. Kukull, W.A., Higdon, R., Bowen, J.D., McCormick, W.C. et al. (2002), 'Dementia and Alzheimer disease incidence: A prospective cohort study', Arch. Neurol. Vol. 59, pp. 1737-1746.

2. Hebert, L.E., Scherr, P.A., Bienias, J.L., Bennett, D.A. et al. (2004), 'State-specific projections through 2025 of Alzheimer disease prevalence', Neurology Vol. 62, p. 1645.

3. Fratiglioni, L., Grut, M., Forsell, Y., Viitanen, M. et al. (1991), 'Prevalence of Alzheimer's disease and other dementias in an elderly urban population: Relationship with age sex, and education', Neurology Vol. 41, pp. 1886-1892.

4. Brookmeyer, R., Gray, S. and Kawas, C. (1998), 'Projections of Alzheimer's disease in the United States and the public health impact of delaying disease onset', Am. J. Public Health Vol. 88, pp. 1337-1342. 
5. McKhann, G., Drachman, D., Folstein, M. et al. (1984), 'Clinical diagnosis of Alzheimer's disease: Report of the NINCDS-ADRDA Work Group under the auspices of Department of Health and Human Services Task Force on Alzheimer's Disease', Neurology Vol. 34, pp. 939-944.

6. Ritchie, K. and Lovestone, S. (2002), 'The dementias', Lancet Vol. 360, pp. $1759-1766$

7. Mosconi, L., Brys, M., Switalski, R., Mistur, R. et al. (2007), 'Maternal family history of Alzheimer's disease predisposes to reduced brain glucose metabolism', Proc. Natl. Acad. Sci. USAVol. 104, pp. 19067-19072.

8. Small, G.W., Bookheimer, S.Y., Thompson, P.M. et al. (2008), 'Current and future uses of neuroimaging for cognitively impaired patients', Lancet Neurol. Vol. 7, pp. 161-172.

9. Scheltens, P., Fox, N., Barkhof, F. and De Carli, C. (2002), 'Structural magnetic resonance imaging in the practical assessment of dementia: Beyond exclusion', Lancet Neurol. Vol. 1, pp. 13-21.

10. Mosconi, L. (2005), 'Brain glucose metabolism in the early and specific diagnosis of Alzheimer's disease', Eur. J. Nucl. Med. Mol. Imaging Vol. 32, pp. $486-510$.

11. Silverman, D.H.S., Gambhir, S.S., Huang, H.W., Schwimmer, J. et al. (2002), 'Evaluating early dementia with and without assessment of regional cerebral metabolism by PET: A comparison of predicted costs and benefits', J. Nucl. Med. Vol. 43, pp. 253-266.

12. Herholz, K., Carter, S.F. and Jones, M. (2007), 'Positron emission tomography imaging in dementia', Br. J. Radiol. Vol. 2, pp. 160-167.

13. Mosconi, L., Pupi, A. and de Leon, M.J. (2009), 'Brain glucose hypometabolism and oxidative stress in preclinical Alzheimer's disease', Ann. NY Acad. Sci. Vol. 1147, pp. 180-195.

14. Klunk, W.E., Engler, H., Nordberg, A., Yamming, W. et al. (2004), 'Imaging brain amyloid in Alzheimer's disease with Pittsburgh compound-B', Ann. Neurol. Vol. 55, pp. 306-319.

15. Kemppainen, N., Aalto, S., Wilson, I., Nagren, K. et al. (2006), 'Voxel-based analysis of PET amyloid ligand [11C]PIB uptake in Alzheimer disease', Neurology Vol. 67, pp. 1575-1580.

16. Pike, K.E., Savage, G., Villemagne, V.L., Ng, S. et al. (2007), 'Betaamyloid imaging and memory in non-demented individuals: Evidence for preclinical Alzheimer's disease', Brain Vol. 130, pp. 2837-2844.

17. Mintun, M.A.M., LaRossa, G.N., Sheline, Y.I.M., Dence, C.S.M. et al. (2006), '[11C]PIB in a nondemented population: Potential antecedent marker of Alzheimer disease', Neurology Vol. 67, pp. 446-452.

18. Fagan, A.M., Mintun, M.A., Mach, R.H., Lee, S. et al. (2006), 'Inverse relation between in vivo amyloid imaging load and cerebrospinal fluid', Ann. Neurol. Vol. 59, pp. 512-519.

19. Tanzi, R.E. and Bertram, L. (2001), 'New frontiers in Alzheimer's disease genetics', Neuron Vol. 32, pp. 181-184.

20. St George-Hyslop, P. (2000), 'Molecular genetics of Alzheimer's disease', Biol. Psychiatry Vol. 47, pp. 183-199.

21. Mirra, S.S., Heyman, A., McKeel, D., Sumi, S.M. et al. (1991), 'The consortium to establish a registry for Alzheimer's disease (CERAD). Part II. Standardization of the neuropathologic assessment of Alzheimer's disease', Neurology Vol. 41, pp. 479-486.

22. Price, J.L. and Morris, J.C. (1999), 'Tangles and plaques in nondemented aging and "preclinical" Alzheimer's disease', Ann. Neurol. Vol. 45, pp. $358-368$.

23. Selkoe, D.J. (1997), 'Alzheimer's disease: Genotypes, phenotype, and treatments', Science Vol. 275, pp. 630-631.

24. Lue, L.F., Kuo, Y.M., Roher, A.E., Brachova, L. et al. (1999), 'Soluble amyloid beta peptide concentration as a predictor of synaptic change in Alzheimer's disease', Am. J. Pathol. Vol. 155, pp. 853-862.

25. Yankner, B.A., Davies, L.R., Fisher, S., Villa-Komaroff, L. et al. (1989), 'Neurotoxicity of a fragment of the amyloid precursor associated with Alzheimer's disease', Science Vol. 245, pp. 417-420.

26. Yankner, B.A., Duffy, L. and Kirschner, D. (1990), 'Neurotrophic and neurotoxic effects of amyloid beta protein: Reversal by tachykinin neuropeptides', Science Vol. 250, pp. 279-282.

27. Geula, C., Wu, C.K., Saroff, D., Lorenzo, A. et al. (1998), 'Aging renders the brain vulnerable to amyloid beta-protein neurotoxicity', Nat. Med. Vol. 4, pp. 827-831.
28. Behl, C., Davis, J., Lesley, R. and Schubert, D. (1994), 'Hydrogen peroxide mediates amyloid [beta]protein toxicity', Cell Vol. 77, pp. 817-827.

29. Selkoe, D.J. (2001), 'Clearing the brain's amyloid cobwebs', Neuron Vol. 32, pp. 177-180.

30. Kennedy, A.M., Frackowiak, R.S.J., Newman, S.K., Bloomfield, P.M. et al. (1995), 'Deficits in cerebral glucose metabolism demonstrated by positron emission tomography in individuals at risk of familial Alzheimer's disease', Neurosci. Lett. Vol. 186, pp. 17-20.

31. Mosconi, L., Sorbi, S., de Leon, M.J., Nacmias, B. et al. (2006), 'Hypometabolism exceeds atrophy in presymptomatic early-onset familial Alzheimer's disease', J. Nucl. Med. Vol. 47, pp. 1778-1786.

32. Klunk, W.E., Price, J.C., Mathis, C.A., Tsopelas, N.D. et al. (2007), 'Amyloid deposition begins in the striatum of presenilin-1 mutation carriers from two unrelated pedigrees', J. Neurosci. Vol. 27, pp. 6174-6184.

33. Koivunen, J., Verkkoniemi, S., Aalto, S., Paetau, A. et al. (2008), 'PET amyloid ligand [11C]PIB uptake shows predominantly striatal increase in variant Alzheimer's disease', Brain Vol. 131, pp. 1845-1853.

34. Remes, A.M., Laru, L., Tuominen, H., Aalto, S. et al. (2008), 'Carbon 11-labeled Pittsburgh compound B positron emission tomographic amyloid imaging in patients with APP locus duplication', Arch. Neurol. Vol. 65 , pp. $540-544$.

35. Di Fede, G., Catania, M., Morbin, M., Rossi, G. et al. (2009), 'A recessive mutation in the APP gene with dominant-negative effect on amyloidogenesis', Science Vol. 323, pp. 1473-1477.

36. Tomiyama, T., Nagata, T., Shimada, H., Teraoka, R. et al. (2008), 'A new amyloid B variant favoring oligomerization in Alzheimer's-type dementia', Ann. Neurol. Vol. 63, pp. 377-387.

37. Gatz, M., Reynolds, C.A., Fratiglioni, L., Johansson, B. et al. (2006), 'Role of genes and environments for explaining Alzheimer disease', Arch. Gen. Psychiatry Vol. 63, pp. 168-174.

38. Gatz, M., Pedersen, N.L., Berg, S., Johansson, B. et al. (1997), 'Heritability for Alzheimer's disease: The study of dementia in Swedish twins', J. Gerontol. A Biol. Sci. Med. Sci. Vol. 52, pp. 117-125.

39. Raiha, I., Kaprio, J., Koskenvuo, M., Johansson, B. et al. (1996), 'Alzheimer's disease in Finnish twins', Lancet Vol. 347, pp. 573-578

40. Strittmatter, W.J., Saunders, A.M., Schmechel, D., Pericak-Vance, M. et al. (1993), 'Apolipoprotein E: High-avidity binding to $\beta$-amyloid and increased frequency of type 4 allele in late-onset familial Alzheimer disease', Proc. Natl. Acad. Sci. USA Vol. 90, pp. 1977-1981.

41. Schmechel, D.E., Saunders, A.M., Strittmatter, W.J., Crain, B.J. et al. (1993), 'Increased amyloid beta-peptide deposition in cerebral cortex as a consequence of apolipoprotein $\mathrm{E}$ genotype in late-onset Alzheimer disease', Proc. Natl. Acad. Sci. USA Vol. 90, pp. 9649-9653.

42. Holtzman, D.M., Bales, K.R., Tenkova, T., Fagan, A.M. et al. (2000), 'Apolipoprotein $\mathrm{E}$ isoform-dependent amyloid deposition and neuritic degeneration in a mouse model of Alzheimer's disease', Proc. Natl. Acad. Sci. USA Vol. 97, pp. 2892-2897.

43. Holtzman, D.M. (2001), 'Role of apoE/A interactions in the pathogenesis of Alzheimer's disease and cerebral amyloid angiopathy', J. Mol. Neurosci. Vol. 17, pp. 147-155.

44. DeMattos, R.B. (2004), 'Apolipoprotein E dose-dependent modulation of beta-amyloid deposition in a transgenic mouse model of Alzheimer's disease', J. Mol. Neurosci. Vol. 23, pp. 255-262.

45. Bennet, D.A., Schneider, J.A., Wilson, R.S., Bienias, J.L. et al. (2005), 'Amyloid mediates the association of apolipoprotein E e4 allele to cognitive function in older people', J. Neurol. Neurosurg. Psych. Vol. 76, pp. 1194-1199.

46. Laws, S.M., Hone, E., Gandy, S. and Martins, R.N. (2003), 'Expanding the association between the APOE gene and the risk of Alzheimer's disease: Possible roles for APOE promoter polymorphisms and alterations in APOE transcription'. J. Neurochem. Vol. 84, pp. 1215-1236.

47. Reiman, E.M., Uecker, A., Caselli, R.J., Lewis, S. et al. (1998), 'Hippocampal volumes in cognitively normal persons at genetic risk for Alzheimer's disease', Ann. Neurol. Vol. 44, pp. 288-291.

48. Geroldi, C., Pihlajamaki, M., Laakso, M.P., DeCarli, C. et al. (1999), 'APOE-epsilon4 is associated with less frontal and more medial temporal lobe atrophy in AD', Neurology Vol. 53, pp. 1825-1832. 
49. Small, G.W., Mazziotta, J.C., Collins, M.T., Baxter, L.R. et al. (1995), 'Apolipoprotein E type 4 allele and cerebral glucose metabolism in relatives at risk for familial Alzheimer disease', JAMA Vol. 273, pp. $942-947$.

50. Small, G.W., Ercoli, L.M., Silverman, D.H.S., Huang, S.C. et al. (2000), 'Cerebral metabolic and cognitive decline in persons at genetic risk for Alzheimer's disease', Proc. Natl. Acad. Sci. USA Vol. 97, pp. 6037-6042.

51. Reiman, E.M., Caselli, R.J., Chen, K., Alexander, G.E. et al. (2001), 'Declining brain activity in cognitively normal apolipoprotein E epsilon 4 heterozygotes: A foundation for using positron emission tomography to efficiently test treatments to prevent Alzheimer's disease', Proc. Natl. Acad. Sci. USA Vol. 98, pp. 3334-3339.

52. Reiman, E.M., Chen, K., Alexander, G.E., Caselli, R.J. et al. (2004), 'Functional brain abnormalities in young adults at genetic risk for late-onset Alzheimer's dementia', Proc. Natl. Acad. Sci. USA Vol. 101, pp. 284-289.

53. Rogaeva, E., Meng, Y., Lee, J.H., Gu, Y. et al. (2007), 'The neuronal sortilin-related receptor SORL1 is genetically associated with Alzheimer disease', Nat. Genet. Vol. 39, pp. 168-177.

54. Lee, J.H., Cheng, R., Schupf, N., Manly, J. et al. (2007), 'The association between genetic variants in SORL1 and Alzheimer disease in an urban, multiethnic, community-based cohort', Arch. Neurol. Vol. 64, pp. $501-506$.

55. Lee, J.H., Shibata, N., Cheng, R. and Mayeux, R. (2008), 'Possible association between SORL1 and Alzheimer disease?', Dement. Geriatr. Cogn. Disord. Vol. 26, p. 482.

56. Meng, Y., Lee, J.H., Cheng, R. and Mayeux, R. (2007), 'Association between SORL1 and Alzheimer disease in a genome-wide study', Neuroreport Vol. 18, pp. 1761-1764.

57. Dodson, S.E., Gearing, M., Lippa, C.F., Montine, T.J. et al. (2006), 'LR11/SorLA expression is reduced in sporadic Alzheimer disease but not in familial Alzheimer disease', J. Neuropathol. Exp. Neurol. Vol. 65, pp. $866-872$.

58. Kolsch, H., Jessen, F., Wiltfang, J., Lewczuk, P. et al. (2008), 'Influence of SORL1 gene variants: Association with CSF amyloid-beta products in probable Alzheimer's disease', Neurosci. Lett. Vol. 440, pp. 68-71.

59. Cuenco, K.T., Lunetta, K.L., Baldwin, C.T., McKee, A.C. et al. (2008), 'Association of distinct variants in SORL1 with cerebrovascular and neurodegenerative changes related to Alzheimer disease', Arch. Neurol. Vol. 65, pp. 1640-1648.

60. Reiman, E.M., Webster, J.A., Myers, A.J., Hardy, J. et al. (2007), 'GAB2 alleles modify Alzheimer's risk in APOE e4 carriers', Neuron Vol. 54, pp. 713-720.

61. Sleegers, K., Bettens, K., Brouwers, N., Engelborghs, S. et al. (2008), 'Common variation in GRB-associated binding protein 2 (GAB2) and increased risk for Alzheimer dementia', Hum. Mutat. Vol. 29, pp. $338-344$.

62. Gu, H., Saito, K., Klaman, L.D., Fleming, T. et al. (2001), 'Essential role for Gab2 in the allergic response', Nature Vol. 412, pp. 186-190.

63. Haas, I.G., Frank, M., Veron, N. and Kemler, R. (2005), 'Presenilindependent processing and nuclear function of gamma-protocadherins'. J. Biol. Chem. Vol. 280, pp. 9313-9319.

64. Carrasquillo, M.M., Zou, F, Pankratz, V.S., Wilcox, S.L. et al. (2009), 'Genetic variation in PCDH11X is associated with susceptibility to late-onset Alzheimer's disease', Nat. Genet. Vol. 41, pp. 192-198.

65. Papassotiropoulos, A., Stephan, D.A., Huentelman, M.J., Hoerndli, FJ. et al. (2006), 'Common KIBRA alleles are associated with human memory performance', Science Vol. 314, pp. 475-478.

66. Almeida, O.P., Schwab, S.G., Lautenschlager, N.T., Morar, B. et al. (2008), 'KIBRA genetic polymorphism influences episodic memory in later life, but does not increase the risk of mild cognitive impairment', J. Cell. Mol. Med. Vol. 12, pp. 1672-1676.

67. Corneveaux, J.J., Liang, W.S., Reiman, E.M. et al. (2008), 'Evidence for an association between KIBRA and late-onset Alzheimer's disease', Neurobiol. Aging doi:10.1016/jneurobiolaging2008.07. [Epub ahead of print]
68. Rodriguez-Rodriguez, E., Infanti, J., Llorca, J., Mateo, I. et al. (2009), 'Age-dependent association of KIBRA genetic variation and Alzheimer's disease risk', Neurobiol. Aging Vol. 30, pp. 322-324.

69. Mayeux, R. and Hyslop, P.S. (2008), 'Alzheimer's disease: Advances in trafficking', Lancet Neurol. Vol. 7, pp. 2-3.

70. Farrer, L.A., Cupples, L.A., Haines, J.L., Hyman, B. et al. (1997), 'Effects of age, sex, and ethnicity on the association between apolipoprotein E genotype and Alzheimer disease', JAMA Vol. 278, pp. $1349-1356$.

71. Silverman, J.M., Raiford, K., Edland, S., Fillenbaum, G. et al. (1994), 'The consortium to establish a registry for Alzheimer's disease (CERAD). Part VI. Family history assessment: A multicenter study of first degree relatives of Alzheimer's disease probands and nondemented spouse controls', Neurology Vol. 44, pp. 1253-1259.

72. Cupples, L.A., Farrer, L.A., Sadovnik, A.D., Relkin, N. et al. (2004), 'Estimating risk curves for first-degree relatives of patients with Alzheimer's disease: The REVEAL study', Genet. Med. Vol. 6, pp. 192-196.

73. Green, R.C., Cupples, L.A., Go, R., Benke, K.S. et al. (2002), 'Risk of dementia among white and African American relatives of patients with Alzheimer disease', JAMAVol. 287, pp. 329-336.

74. Silverman, J.M., Ciresi, G., Smith, C.J., Marin, D.B. et al. (2005), 'Variability of familial risk of Alzheimer disease across the late life span', Arch. Gen. Psychiat. Vol. 62, pp. 565-573.

75. Jayadev, S., Steinbart, E.J., Chi, Y.Y., Kukull, W.A. et al. (2008), 'Conjugal Alzheimer disease', Arch. Neurol. Vol. 65, pp. 373-378.

76. Bird, T.D., Nemens, E.J. and Kukull, W.A. (1993), 'Conjugal Alzheimer's disease: Is there an increased risk in offspring?', Ann. Neurol. Vol. 34, pp. 396-399.

77. Duara, R., Lopez-Alberola, R.F., Barker, W.W., Loewenstein, D.A. et al. (1993), 'A comparison of familial and sporadic Alzheimer's disease', Neurology Vol. 43, pp. 1377-1384.

78. Edland, S.D., Silverman, J.M., Peskind, E.R., Tsuang, D. et al. (1996), 'Increased risk of dementia in mothers of Alzheimer's disease cases: Evidence for maternal inheritance', Neurology Vol. 47, pp. 254-256.

79. Ehrenkrantz, D., Silverman, J.M., Smith, C.J., Tsuang, D. et al. (1999), 'Genetic epidemiological study of maternal and paternal transmission of Alzheimer's disease'. Am. J. Med. Genet. Vol. 88, pp. 378-382.

80. Gomez-Tortosa, E., Barquero, M.S., Baron, M., Saint, H.J. et al. (2007), 'Variability of age at onset in siblings with familial Alzheimer disease'. Arch. Neurol. Vol. 64, pp. 1743-1748.

81. Heyman, A., Wilkinson, W.E., Hurwitz, B.J., Schmechel, D. et al. (1983), 'Alzheimer's disease: Genetic aspects and associated clinical disorders', Ann. Neurol. Vol. 14, pp. 507-515.

82. Seshadri, S., Wolf, P.A., Beiser, A., Au, R. et al. (1996), 'Lifetime risk of dementia and Alzheimer's disease: Estimates from the Framingham study', Neurology Vol. 46, pp. 411-412.

83. Duara, R., Barker, W.W., Lopez-Alberola, R., Loewenstein, D.A. et al. (1996), 'Alzheimer's disease: Interaction of apolipoprotein E genotype, family history of dementia, gender, education, ethnicity, and age of onset', Neurology Vol. 46, pp. 1575-1579.

84. Mosconi, L., Mistur, R., Glodzik, L., Brys, M. et al. (2009), 'Declining brain glucose metabolism in normal individuals with a maternal history of Alzheimer's', Neurology Vol. 72, pp. 513-520.

85. de Leon, M.J., Convit, A., Wolf, O.T., Tarshish, C.Y. et al. (2001), 'Prediction of cognitive decline in normal elderly subjects with 2-[18F]fluoro-2-deoxy-D-glucose/positron-emission tomography (FDG/PET)', Proc. Natl. Acad. Sci. USA Vol. 98, pp. 10966-10971.

86. Mosconi, L., De Santi, S., Li, J., Tsui, W.H. et al. (2008), 'Hippocampal hypometabolism predicts cognitive decline from normal aging', Neurobiol. Aging Vol. 29, pp. 676-692.

87. Constancia, M., Kelsey, G. and Relk, W. (2004), 'Resourceful imprinting', Nature Vol. 432, pp. 53-57.

88. Gold, J.D. and Pedersen, R.A. (1994), 'Mechanisms of genomic imprinting in mammals', Curr. Top. Dev. Biol. Vol. 29, pp. 227-280.

89. Moore, T. and Haig, D. (1991), 'Genomic imprinting in mammalian development: A parental tug-of-war', Trends Genet. Vol. 7, pp. 45-49. 
90. Payao, S.L., Smith, M.D. and Bertolucci, P.H. (1998), 'Differential chromosome sensitivity to 5-azacytidine in Alzheimer's disease', Gerontology Vol. 44, pp. 267-271.

91. Bassett, S.S., Avramopoulos, D. and Fallin, D. (2002), 'Evidence for parent of origin effect in late-onset Alzheimer disease', Am. J. Med. Genet. Vol. 114, pp. 679-686.

92. Csaba, G. (2008), 'Hormonal imprinting: Phylogeny, ontogeny, diseases and possible role in present-day human evolution', Cell Biochem. Funct. Vol. 26, pp. 1-10.

93. Wilkinson, L.S., Davies, W. and Isles, A.R. (2007), 'Genomic imprinting effects on brain development and function', Nat. Rev. Neurosci. Vol. 8, pp. 832-843.

94. Davies, W., Isles, A., Smith, R., Karunadasa, D. et al. (2005), 'Xlr3b is a new imprinted candidate for X-linked parent-of-origin effects on cognitive function in mice', Nat. Genet. Vol. 37, pp. 625-629.

95. Lin, M.T. and Beal, M.F. (2006), 'Mitochondrial dysfunction and oxidative stress in neurodegenerative diseases', Nature Vol. 443, pp. 787-795.

96. Schapira, A.H. (2006), 'Mitochondrial disease', Lancet Vol. 368, pp. $70-82$.

97. Smith, M.A., Sayre, L.M., Monnier, V.M. and Perry, G. (1995), 'Radical AGEing in Alzheimer's disease', Trends Neurosci. Vol. 18, pp. 172-176.

98. Mecocci, P., MacGarvey, U. and Beal, M.F. (1994), 'Oxidative damage to mitochondrial DNA is increased in Alzheimer's disease', Ann. Neurol. Vol. 36, pp. 747-750.

99. Subbarao, K.V., Richardson, J.S. and Ang, L.C. (1990), 'Autopsy samples of Alzheimer's cortex show increased peroxidation in vitro'. J. Neurochem. Vol. 55, pp. 342-345

100. Swerdlow, R.H. (2007), 'Treating neuro degeneration by modifying mitochondria: Potential solutions to a "complex" problem', Antiox. Redox Signal. Vol. 9, pp. 1591-1604.

101. Mutisya, E.M., Bowling, A.C. and Beal, M.F. (1994), 'Cortical cytochrome oxidase activity is reduced in Alzheimer's disease', J . Neurochem. Vol. 63, pp. 2179-2184.

102. Hirai, K., Aliev, G., Nunomura, A., Fujioka, H. et al. (2001), 'Mitochondrial abnormalities in Alzheimer's disease', J. Neurosci. Vol. 21, pp. 3017-3023.

103. Valla, J., Berndt, J.D. and Gonzales-Lima, F. (2001), 'Energy hypometabolism in posterior cingulate cortex of Alzheimer's patients: Superficial laminar cytochrome oxidase associated with disease duration', J. Neurosci. Vol. 21, pp. 4923-4930.

104. Simonian, N.A. and Hyman, B.T. (1994), 'Functional alterations in Alzheimer's disease: Selective loss of mitochondrial-encoded cytochrome oxidase mRNA in the hippocampal formation', J. Neuropathol. Exp. Neurol. Vol. 53, pp. 508-512.

105. Wong-Riley, M.T.T. (1989), 'Cytochrome oxidase: An endogenous metabolic marker for neuronal activity', Trends Neurosci. Vol. 12, pp. 94-101.

106. Hevner, R.F. and Wong-Riley, M.T. (1991), 'Neuronal expression of nuclear and mitochondrial genes for cytochrome oxidase (CO) subunits analyzed by in situ hybridization: Comparison with $\mathrm{CO}$ activity and protein', J. Neurosci. Vol. 11, pp. 1942-1958.

107. Parker, W.D., Jr, Filley, C.M. and Parks, J.K. (1990), 'Cytochrome oxidase deficiency in Alzheimer's disease', Neurology Vol. 40, pp. 1302-1303.

108. Parker, W.D., Jr, Mahr, N.J., Filley, C.M., Parks, J.K. et al. (1994), 'Reduced platelet cytochrome c oxidase activity in Alzheimer's disease', Neurology Vol. 44, pp. 1086-1090.

109. Chandrasekaran, K., Hatanpää, K., Rapoport, S.I. and Brady, D.R. (1997), 'Decreased expression of nuclear and mitochondrial DNAencoded genes of oxidative phosphorylation in association neocortex in Alzheimer disease', Brain Res. Mol. Brain Res. Vol. 44, pp. 99-104.

110. Bosetti, F, Brizzi, F., Barogi, S., Mancuso, M. et al. (2002), 'Cytochrome c oxidase and mitochondrial F1F0-ATPase (ATP synthase) activities in platelets and brain from patients with Alzheimer's disease', Neurobiol. Aging Vol. 23, pp. 371-376.

111. Cardoso, S.M., Proenca, M.T., Santos, S. and de Oliveira, C.R. (2004), 'Cytochrome c oxidase is decreased in Alzheimer's disease platelets', Neurobiol. Aging Vol. 25, pp. 105-110.
112. Valla, J., Schneider, L., Niedzielko, T., Coon, K.D. et al. (2006), 'Impaired platelet mitochondrial activity in Alzheimer's disease and mild cognitive impairment', Mitochondrion Vol. 6, pp. 323-330.

113. Curti, D., Rognoni, F., Gasparini, L., Cattaneo, A. et al. (1997), 'Oxidative metabolism in cultured fibroblasts derived from sporadic Alzheimer's disease (AD) patients', Neurosci. Lett. Vol. 236, pp. 13-16.

114. Kish, S.J., Bergeron, C., Rajput, A.H., Dozic, S. et al. (1992), 'Brain cytochrome oxidase in Alzheimer's disease', J. Neurochem. Vol. 59, pp. 776-779.

115. Lucas, J.J. and Kates, J.R. (1976), 'The construction of viable nuclearcytoplasmic hybrid cells by nuclear transplantation', Cell Vol. 7, pp. 397-405.

116. Swerdlow, R.H. and Khan, S.M. (2004), 'A "mitochondrial cascade hypothesis” for sporadic Alzheimer's disease', Med. Hypotheses Vol. 63, pp. $8-20$.

117. Swerdlow, R.H., Parks, J.K., Cassarino, D.S., Maguire, D.J. et al. (1997), 'Cybrids in Alzheimer's disease: A cellular model of the disease?', Neurology Vol. 49, pp. 918-925.

118. Khan, S.M., Cassarino, D.S., Abramova, N.N., Keeney, P.M. et al. (2000), 'Alzheimer's disease cybrids replicate beta-amyloid abnormalities through cell death pathways', Ann. Neurol. Vol. 48, pp. 148-155.

119. Trimmer, P.A., Swerdlow, R.H., Parks, J.K., Keeney, P.M. et al. (2000), 'Abnormal mitochondrial morphology in sporadic Parkinson's and Alzheimer's disease cybrid cell lines', Exp. Neurol. Vol. 162, pp. 37-50.

120. Cardoso, S.M., Santana, I., Swerdlow, R.H. and Oliveira, C.R. (2004), 'Mitochondria dysfunction of Alzheimer's disease cybrids enhances Abeta toxicity', J. Neurochem. Vol. 89, pp. 1417-1426.

121. Coskun, P.E., Beal, M.F. and Wallace, D.C. (2004), 'Alzheimer's brains harbor somatic mtDNA controlregion mutations that suppress mitochondrial transcription and replication', Proc. Natl. Acad. Sci. USA Vol. 101, pp. 10726-10731.

122. Chinnery, P.F, Taylor, G.A., Howell, N., Brown, D.T. et al. (2001), 'Point mutations of the mtDNA control region in normal and neurodegenerative human brains', Am. J. Hum. Genet. Vol. 68, pp. 529-532.

123. Corral-Debrinski, M., Horton, T., Lott, M.T., Shoffner, J.M. et al. (1994), 'Marked changes in mitochondrial DNA deletion levels in Alzheimer brains', Genomics Vol. 23, pp. 471-476.

124. Egensperger, R., Kosel, S., Schnopp, N.M., Mehraein, P. et al. (1997) 'Association of the mitochondrial tRNA(A4336G) mutation with Alzheimer's and Parkinson's diseases', Neuropathol. Appl. Neurobiol. Vol. 23, pp. 315-321.

125. Shoffner, J.M., Brown, M.D., Torroni, A., Lott, M.T. et al. (1993), 'Mitochondrial DNA variants observed in Alzheimer disease and Parkinson disease patients', Genomics Vol. 17, pp. 171-184.

126. Wragg, M.A., Talbot, C.J., Morris, J.C., Lendon, C.L. et al. (1995), 'No association found between Alzheimer's disease and a mitochondrial tRNA glutamine gene variant', Neurosci. Lett. Vol. 201, pp. 107-110.

127. Carrieri, G., Bonafe, M., De Luca, M., Rose, G. et al. (2001), 'Mitochondrial DNA haplogroups and APOE4 allele are nonindependent variables in sporadic Alzheimer's disease', Hum. Genet. Vol. 108, pp. 194-198.

128. van der Walt, J.M., Dementieva, Y.A., Martin, E.R., Scott, W.K. et al. (2004), 'Analysis of European mitochondrial haplogroups with Alzheimer disease risk', Neurosci. Lett. Vol. 365, pp. 28-32.

129. Chagnon, P., Gee, M., Filion, M., Robitaille, Y. et al. (1999), 'Phylogenetic analysis of the mitochondrial genome indicates significant differences between patients with Alzheimer disease and controls in a French-Canadian founder population', Am. J. Med.Genet. Vol. 85, pp. 20-30.

130. Brouwer, J.R., Willemsen, R. and Oostra, B.A. (2009), 'Microsatellite repeat instability and neurological disease', Bioessays Vol. 31, pp. 71-83.

131. Kehoe, J.P., Krawczak, M., Harper, P.S., Owen, M.J. et al. (1999), 'Age of onset in Huntington disease: Sex specific influence of apolipoprotein E genotype and normal CAG repeat length', J. Med. Genet. Vol. 36, pp. $108-111$.

132. Mandel, J.L. and Biancalana, V. (2004), 'Fragile X mental retardation syndrome: From pathogenesis to diagnostic issue', Growth Horm. IGF Res. Vol. 14 (Suppl. 1), pp. 158-165. 
133. La Pean, A., Jeffries, N., Grow, C., Ravina, B. et al. (2008), 'Predictors of progression in patients with Friedreich ataxia', Mov. Disord. Vol. 23, pp. $2026-2032$.

134. Botta, A., Rinaldi, F., Catalli, C., Vergani, L. et al. (2009), 'The CTG repeat expansion size correlates with the splicing defects observed in muscles from myotonic dystrophy type 1 patients', J .Med. Genet. Vol. 45 , pp. 639-646

135. Ashworth, A., Lloyd, S., Brown, J., Gydesen, S. et al. (1999), 'Molecular genetic characterisation of frontotemporal dementia on chromosome 3', Dement. Geriatr. Cogn. Disord. Vol. 10, pp. 93-101.

136. Mackenzie, I.R., Butland, S.L., Devon, R.S., Dwosh, E. et al. (2006), 'Familial frontotemporal dementia with neuronal intranuclear inclusions is not a polyglutamine expansion disease', BMC Neurol. Vol. 6, pp. $32-38$.

137. Samii, A., Nutt, J.G. and Ransom, B.R. (2004), 'Parkinson's disease', Lancet Vol. 363, pp. 1783-1793.

138. Wider, C. and Wszolek, Z.K. (2009), 'Movement disorders: Insights into mechanisms and hopes for treatment', Lancet Neurol. Vol. 8, pp. 8-10.

139. Banerjee, R., Starkov, A.A., Beal, M.F. and Thomas, B. (2008), 'Mitochondrial dysfunction in the limelight of Parkinson's disease pathogenesis', Biochim. Biophys. Acta Vol. 1792, pp. 651-663.

140. Swerdlow, R.H., Parker, W.D., Currie, L.J., Bennett, J.P. et al. (2001), 'Gender ratio differences between Parkinson's disease patients and their affected relatives', Parkinsonism Relat. Disord. Vol. 7, pp. 129-133.

141. Wooten, G.F., Currie, L.J., Bennet, J.P., Harrison, M.B. et al. (1997), 'Maternal inheritance in Parkinson's disease', Ann. Neurol. Vol. 41, pp. $265-268$.

142. van der Walt, J.M., Nicodemus, K.K., Martin, E.R., Scott, W.K. et al. (2003), 'Mitochondrial polymorphisms significantly reduce the risk of Parkinson disease', Am. J. Hum. Genet. Vol. 72, pp. 804-811.

143. Pyle, A., Foltynie, T., Tiangyou, W., Lambert, C. et al. (2005), 'Mitochondrial DNA haplogroup cluster UKJT reduces the risk of PD', Ann. Neurol. Vol. 57, pp. 564-567.

144. Autere, J., Moilanen, J.S., Finnila, S., Soininen, H. et al. (2004), 'Mitochondrial DNA polymorphisms as risk factors for Parkinson's disease and Parkinson's disease dementia', Hum. Genet. Vol. 115, pp. 29-35.

145. Kirchner, S.C., Hallagan, S.E., Farin, F.M., Dilley, J. et al. (2000), 'Mitochondrial ND1 sequence analysis and association of the T4216C mutation with Parkinson's disease', Neurotoxicology Vol. 21, pp. $441-445$.

146. Huerta, C., Castro, M.G., Coto, E., Blazquez, M. et al. (2005), 'Mitochondrial DNA polymorphisms and risk of Parkinson's disease in Spanish population', J. Neurol. Sci. Vol. 236, pp. 49-54.

147. Tan, E.K., Khajavi, M., Thornby, J.I., Nagamitsu, S. et al. (2000), 'Variability and validity of polymorphism association studies in Parkinson's disease', Neurology Vol. 55, pp. 533-538.

148. Langston, J.W., Ballard, P.A., Tetrud, J.W. and Irwin, I. (1983), 'Chronic parkinsonism in humans due to a product of meperidine-analog synthesis', Science Vol. 219, pp. 979-980.

149. Betarbet, R., Sherer, T.B., MacKenzie, G., Garcia-Osuna, M. et al. (2000), 'Chronic systemic pesticide exposure reproduces features of Parkinson's disease', Nat. Neurosci. Vol. 3, pp. 1301-1306.

150. Schapira, A.H.V., Cooper, J.M., Dexter, D., Jenner, P. et al. (1989), 'Mitochondrial complex I deficiency in Parkinson's disease', Lancet Vol. 1, p. 1269.

151. Bindoff, L.A., Birch-Machin, M., Cartlidge, N.E.F, Parker, W.D.J. et al (1989), 'Mitochondrial function in Parkinson's disease', Lancet Vol. 2, p. 49.

152. Parker, W.D., Jr, Boyson, S.J. and Parks, J.K. (1989), 'Electron transport chain abnormalities in idiopathic Parkinson's disease', Ann. Neurol. Vol. 26, pp. 719-723
153. Schapira, A.H. (2007), 'Mitochondrial dysfunction in Parkinson's disease', Cell Death Differ. Vol. 14, pp. 1261-1266.

154. Swerdlow, R.H., Parks, J.K., Miller, S.W., Tuttle, J.B. et al. (1996), 'Origin and functional consequences of the complex I defect in Parkinson's disease', Ann. Neurol. Vol. 40, pp. 663-671.

155. Swerdlow, R.H. (2007), 'Mitochondria in cybrids containing mtDNA from persons with mitochondriopathies', J. Neurosci. Res. Vol. 85, pp. 3416-3428.

156. Swerdlow, R.H., Parks, J.K., Davis, J.N., Cassarino, D.S. et al. (1998), 'Matrilineal inheritance of complex I dysfunction in a multigenerational Parkinson's disease family', Ann. Neurol. Vol. 44, pp. 873-881.

157. Maceluch, J.A. and Niedziela, M.(2007), 'The clinical diagnosis and molecular genetics of Kearns-Sayre syndrome: A complex mitochondrial encephalomyopathy', Pediatr. Endocrinol. Rev. Vol. 4 , pp. $117-137$.

158. Thambisetty, M. and Newman, N.J. (2004), 'Diagnosis and management of MELAS', Expert Rev. Mol. Diagn. Vol. 4, pp. 631-644.

159. DiMauro, S., Hirano, M., Kaufmann, P., Tanji, K. et al. (2002), 'Clinical features and genetics of myoclonic epilepsy with ragged red fibers', Adv. Neurol. Vol. 89, pp. 217-229.

160. Holt, I.J., Harding, A.E., Petty, R.K.H. and Morgan-Hughes, J.A. (1990), 'A new mitochondrial disease associated with mitochondrial DNA heteroplasmy', Am. J. Hum. Genet. Vol. 46, pp. 428-433.

161. Yen, M.Y., Wang, A.G. and Wei, Y.H. (2006), 'Leber's hereditary optic neuropathy: A multifactorial disease', Prog. Retin. Eye Res. Vol. 25, pp. 381-396

162. Silvestri, G., Servidei, S., Rana, M., Ricci, E. et al. (1996), 'A novel mitochondrial DNA point mutation in the tRNAIle gene is associated with progressive external ophthalmoplegia', Biochem. Biophys. Res. Comm. Vol. 220, pp. 623-627.

163. Hosszufalusi, N., Karcagi, V., Horvath, R., Palik, E. et al. (2009), 'A detailed investigation of maternally inherited diabetes and deafness (MIDD) including clinical characteristics, C-peptide secretion, HLA-DR and -DQ status and autoantibody pattern', Diabetes Metab. Res. Rev. Vol. 25, pp. 127-135.

164. Pal, D.K., Durner, M., Klotz, I., Dicker, E. et al. (2006), 'Complex inheritance and parent-of-origin effect in juvenile myoclonic epilepsy', Brain Dev. Vol. 28, pp. 92-98.

165. Eapen, V., O’Neill, J., Gurling, H.M. and Robertson, M.M. (1997), 'Sex of parent transmission effect in Tourette's syndrome: Evidence for earlier age at onset in maternally transmitted cases suggests a genomic imprinting effect', Neurology Vol. 48, pp. 801-802.

166. Horsthemke, B. and Wagstaff, J. (2008), 'Mechanisms of imprinting of the Prader-Willi/Angelman region', Am. J. Med. Genet. Vol. 146, pp. 2041-2052.

167. Cook, E.H., Jr, Lindgren, V., Leventhal, B.L., Courchesne, R. et al. (1997), 'Autism or atypical autism in maternally but not paternally derived proximal 15q duplication', Am. J. Hum. Genet. Vol. 60, pp. 928-934.

168. Brown, M.D., Starikovskaya, E., Derbeneva, O., Hosseini, S. et al. (2002), 'The role of mtDNA background in disease expression: A new primary LHON mutation associated with Western Eurasian haplogroup', J. Hum. Genet. Vol. 110, pp. 130-138.

169. Selkoe, D.J. (2001), 'Presenilin, Notch, and the genesis and treatment of Alzheimer's disease', Proc. Natl. Acad. Sci. USA Vol. 98, pp. 11039-11041.

170. Bothwell, M. and Giniger, E. (2000), 'Alzheimer's disease: Neurodevelopment converges with neurodegeneration', Cell Vol. 102, pp. 271-273.

171. Nikolaev, A., McLaughlin, T., O'Leary, D.D. and Tessier-Lavigne, M. (2009), 'APP binds DR6 to trigger axon pruning and neuron death via distinct caspases', Nature Vol. 457, pp. 981-989. 